
\title{
mülafakif
} Cilt:2 •Sayı:3 • Haziran • 2015 •s.107-135

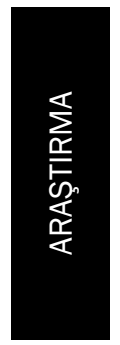

\section{ABDÜRREZZÂK KÂŞÂNî (ö. 730/1330) VE TEFSIRDEKI METODU*}

\author{
Mehmet KAYA**
}

Öz

Abdürrezzâk Kâşânî (ö. 730/1330) otuz beș eser vermesine ve Davud-u Kayserî (ö. 751/1350), İsmail Hakkı Bursevî (ö.1137/1725), Âlûsî (ö. 1270/1854), Cemâleddin el-Kâsımî (ö. 1332/1914) gibi müfessirleri etkilemiş olmasına rağmen ilim dünyasında hak ettiği yeri alamamış, ayrıca sufi olmasına rağmen Bâtıni olmakla itham edilmiştir. Kâşânî'nin, Hakâiku't-Te'vîl adlı tefsirinin te'vîl bölümlerinden oluşan Te'vîlâtü'l-Kur'ân'ı ise defalarca Tefsîri Şeyhi'I-Ekber adıyla İbn Arabî (ö. 638/1240)'ye nispet edilerek basılmış ve bu isimle şöhret bulmuştur. Kâşânî̀ye aidiyeti kesin olan bu eserde işarî tefsir yöntemi ağır basmakla birlikte yer yer literal yorumlara da rastlanılmaktadır. Ayrıca eserde antropomorfist ve hurufi çizgide yorumlar da yapılmıştır. Biz bu çalışmada, işarî tefsirin vahdeti vücut döneminde yaşamış olan Abdürrezzâk Kâşânî ve tefsiri Te'vîlâtü'l-Kur'ân'ı inceleyeceğiz.

Anahtar Kelimeler:Tefsir, ișarî tefsir, tasavvuf, Abdürrezzâk Kâșânî, Te'vîlâtü'lKur'an.

\section{Abd al-Razzâk al-Kāshânî and His Commentery Method Abstract}

Although Abd al-Razzâk al-Kāshânî (d. 730/1330) left more than thirty works and effected commentators like Dâwûd al-Qaysarî (d. 751/1350), Ismail Haqqi Bursawi (d. 1137/1725), Alusi (d. 1270/1854), and Jamaluddin al Qasimi (d. 1866-1913) he couldn't take the place he deserved in the world of science. Furthermore, though he was a Sufi, he was accused of being withinBatiniya. Kāshânî's Tawilat al-Qur'an which is composed of the sections of te'vil of his commentary which is named Haqaiq al-Tawil repeatedly published in the name of Tafseer Sheikh Akbar by attributing to İbn Arabî (d. 638/1240) and found fame with that name. Although the method of issari interpretation in this work which precisely belongs to al-Kāshânî prevailed the literal interpretation, it is also observed in places. In addition, anthropomorphic and hurufi comments were made in the work. In this study, we will research Abd al-Razzâk al-Kāshânî who lived in pantheist period of mystical interpretation and his commentary Tawilat al-Qur'an.

Keywords: Tafsir, mystic commentery, sufism, Abd al-Razzâk al-Kāshânî, Tawilat al-Qur'an. 


\section{GiRiş}

Abdürrezzâk Kâşânî, işarî tefsirin vahdeti vücut akımı1 içerisinde yetişmiş, gerek tefsirin bu dalında, gerekse tasavvuf sahasında -bilindiği kadarıyla- otuz beş eser kaleme almış sufimüfessirdir. Yazmış olduğu eserler onun zahir ve bâtın ilmindeki derinliğini göstermesi açııından yeterlidir. Abdürrezzâk Kâşânî, tefsir alanında Hakâiku't-Te'vîl ve Dekâiku't-Tenzîl, adlı tefsir ile onun muhtasarı Te'vîlâtü'lKur'an adlı işarî tefsiri kaleme almış, kelâm alanında Risâletü'l-Kazâ ve'l-Kader, tasavvuf alanında Istılâhâtu's-Sûfiyye adlı eserleri yazmış ve kendisinden sonraki hemen her mutasavvıfı etkileyen ve müstakil bir tasavvuf ekolü vücuda getirmiş olan İbn Arabî'ninFusûsu'l-Hikem, Herevî (ö. 408/1018)'nin Menâzilu's-Sâirîn, ỉbn Fârıd (ö. 632/1235)'ın Tâiyyetü'l-Kübrâ adlı eserlerine şerhler yazmış olmasına rağmen yeterince tanınmadığı gibi2 ${ }^{2}$ Matla 'u's-Sa‘deyn müellifi tarihçi Abdürrezzâk b. İshâk es-Semerkandî el-Kâşânî (ö. 887/1482) ile karıştırılmıştır. ${ }^{3}$ Ayrıca, güçlü bir mutasavvif olan ve vahdeti vücut düşüncesinin sistemleşmesinde büyük bir payı olan Kâşânî, Batınîolmakla da itham edilmiştir.

Kâşânî'nin tefsiri Te'vîlâtü'l-Kur'an da ilim dünyasında hak ettiği yeri alamamıştır. İsmail HakkıBursevî, Âlûsî ve Cemaleddin el-Kâsımî gibi müfessirlerin temel kaynaklarından biri olan eser, bilinmeyen bir sebeple defalarca İbn Arabî'ye nispetle Tefsîr-i ibn Arabî adıyla basılmış ve özellikle işarî tefsir sahasında hak ettiği yeri alamamıştır.

\section{KÂŞÂNÎ'NIN HAYATI}

Eserlerde Kâşânî'nin doğduğu yer, yıl, ailesi ve hayatı hakkında yeterli bilgi onun hayatı ve eserleri hakkındaki az sayıdaki araştırma da çoğunlukla son dö-

* Bu makale, Kemâlüddîn Abdürrezzâk Kâşânî ve Tefsiri Te'vîlâtü'l-Kur'ân'ın Tefsir Metodolojisi Açısından Tahlil ve Tanıtımı, (Erciyes Ü. Sos. Bil. Ens. Kayseri, 2009) adlı Yüksek Lisans tezimin gözden geçirilmesi ile oluşturulmuştur.

** Yrd. Doç. Dr., Aksaray Üniversitesi, İslami İlimler Fakültesi, Tefsir Anabilim Dalı Öğretim Üyesi. E-posta: kayamehmet1453@hotmail.com

1 Vahdeti vücut, Tanrı-alem ikiliğini kaldıran, Tanrının her şeyi intiva ettiğini, hatta O'nun her şey olduğunu, dolayısıyla ne tabiatın ne de insanın müstakil varlıklar gibi görülebileceğini, onların sadece ilahi varlığın farklı tarzlardaki açııımlarından ibaret olduğunu ileri süren dinî ve felsefî bir doktrindir. Bu düşünceyi sistemleştiren ve tasavvufa, dolayısıyla da tefsir ilmine girmesine sebep olan kişi de ibn Arabî'dir. Konu hakkında ayrıntılı bilgi için bk. Konevî, Sadreddin, Vahdet-i Vücûd ve Esasları, çev. Ekrem Demirli, İz Yayıncılık, İstanbul, 2012;Aydın, Mehmet, Din Felsefesi, İzmir, 1992, s. 179; Ateş, Süleyman, Işarî Tefsîr Okulu, Ankara Ü.i..F. Yay., Ankara, 1974, ss. 260-279; Demirli, Ekrem, "Vahdet-i Vücûd",DiA, Ankara, 2012, XXXXII/431-434.

2 Macdonald, D.B.,"Abdürrezzâk Kâşânî", M.E.B.i.A.,İstanbul, 1960, I/106; Uludağ, Süleyman, "Kâşânî Abdürrezâk",DiA, Ankara, 2002, XXV/5;Ergül, Necmeddin, Kâşânî ve Hakâiku't-Te'vîl fî Dekâiki'tTenzîl Adlı Eserinin I. Cildinin (Fâtiha-En'âm) Tahkîk ve Tahrîci, (I-II), (Basılmamış Doktora Tezi, Harran Ü. Sos. Bil. Ens. Şanlıurfa, 2002), I/25; Kaya, Kemâlüddîn Abdürrezzâk Kâşânî,s. 43.

3 Katip Çelebi (Hacı Halîfe), Keşfüzzünûn an Esâmi'l-Kütüb ve'l-Fünûn, M.E.B. Yay., İstanbul, 1971, I/336; Ergül, Kâşânî ve Hakâiku't-Te'vîl, I/31; Kaya, Kemâlüddîn Abdürrezzâk Kâşânî, s. 46; Lory,Pierre, Kâşânî'ye Göre Kur'an'ın Tasavvufi Tefsiri, çev. Sadık Kılıç, İnsan Yay. İstanbul, 2001, s. 25-26; Macdonald, "Abdürrezzâk Kâşânî", s. 106, Uludağ, "Kâşânî Abdürrezzâk" , s. 5. 
nemde kaleme alınmıştır. ${ }^{4}$ Kâşânî'nin hayatı hakkındaki en kapsamlı eser Abdurrahman Cami(ö. 898/1492)'nin Nefehâtü'l-Üns adlı eseridir. Bu eserde de daha çok müfessirin ilmi yönüne dair bilgiler mevcuttur.

İlhanlı Devleti'nin hüküm sürdüğü devirde İran'ın cibal taşrasında yaşayan Abdürrezzâk Kâşânî, yaşadığı devirde iyi bir eğitim görmüş, dönemin yöneticileri ile birlikte bulunmuş bir âlimdir. Hayatı hakkında fazla bilgi bulunmayan müfessirin ismi eserlerde Kemâlüddîn Abdürrezzâk el-Kâşî́, Abdürrezzâk b. Ahmed b. Ebi'lĞanâim Muhammed Cemâlüddin el-Kâşî́, Kemâlüddîn Abdürrezzâk b. Ebi'l-Fedâil el-Kâşânî,7 Kemâlüddîn Abdürrezzâk b. Ahmed b. Ebi'l-Ğanâim el-Kâşî,8 Kemâlüddîn Abdürrezzâk b. Cemâlüddîn Ahmed el-Kâşânî,9 Kemâlüddîn Abdürrezzâk b. Celâlüddîn el-Kâşânî,10 Ebû'l-Ganâ'im Abd er-Rezzâk b. Ahmed elKâşânî,11 şeklinde farklı isim ve künyelerle belirtilmekle birlikte Arapça eserlerde daha çok القاشانى, Türkçe eserlerde ise Kâşânî künyesinin kullanıldığı görülmektedir. Müfessirin, Hakâiku't-Te'vîl fî Dekâiki't-Te'vîl adılı eserinin 729/1329 yılında kendi nüshasından istinsah edilen iki nüshaya (Süleymaniye ktp. Fatih koll. no. 142, Süleymaniye ktp. Süleymaniye koll. 113) yani kendi ifadesine göre isminin “Abdürrezzâk b. Ebi'l-Ğanâim b. Ahmed b. Ebi'l-Fedâil b. Muhammed Kâşânî", olduğu kesinlik kazanmaktadır. ${ }^{12}$ Bu nisbenin Kâşân'da doğanlara verilmesi sebe-

${ }^{4}$ Müellifin hayatı, eserleri, ilmî yönü ve fikirleri hakkında yapılan en eski çalışma Pierre Lory'in Te'vîlâtü'lKur'an'daki bazı tasavvufí konuları inceleyen ve Sadık Kılıç'ın Abdürrezzak Kâşânî'ye Göre Kur'an'ın Tefsiri adıyla tercüme ettiği Fransızca eseridir. Ülkemizde ise Necmettin Ergül tarafından Kâşânî ve Hakâiku't-Te'vîl fi Dekâiki't-Tenzîl Adlı Eserinin I. Cildinin (Fâtiha-En'âm) Tahkîk ve Tahrîci adlı doktora tezi ile bu tezden hareketle kaleme aldığı "Abdurrezzâk Kāşânî (ö. 730/1330)'nin Hayatı, İImîTasavvufi Kişiliği ve Eserleri" (Birey ve Toplum, Bahar, 2013, c. 3, sa. 5, ss. 93-125) adlı makale ile Abdürrahim Alkıș'ın "Sermediyet ve Abdurrezzâk-ı Kāșânînin Risâle fî Beyâni Mikdâri's-Seneti'sSermediyye ve Ta yîni Eyyâmi'l-ilâhiyye İsimli Eseri”, (Marmara Ü.i.F.D., 2009/1, sa.36, ss. 207-235), adlı makalesi ve Mehmet Kaya'nın Kemâlüddîn Abdürrezzâk Kâşânî ve Tefsiri Te'vîlâtü'ı-Kur'an'ın Tefsir Metodolojisi Açısından Tahlil ve Tanıtımı adlı yüksek lisans tezi yapılmıştır.

${ }^{5}$ Cami, Abdurrahman, Nefehâtü'l Üns min Hadarât'il Kuds çev.ve şerh Lâmiî Çelebi, byy.,ts., s. 68; Katip Çelebi, Keşfüzzünûn, II/1264; Udnerevî, Ahmed b. Muhammed, Tabakâtu'I-Müfessirîn, tahk. Süleyman b. Salih el-Hızzî, Medînetü’l-Münevvere, 1997, s. 271.

6 Nuveyhid, Adil, Mu 'cemu'l-Müfessirîn min Sadri'l-İslâm Hatta'l- 'Aşri'l-Hâdır, Beyrut, 1983, I/281.

7 Serkis, Yusuf ilyân, Mu 'cemu'l-Matbûa 'ti'al-Arabiyye ve'l-Muarrabe, Kahire, ts. II/1478.

8 Kâtip Çelebi, Keşfüzzünûn, II/1263.

9 Kâtip Çelebi, Keşfüzzünûn, I/266; Mollaibrahimoğlu, Süleyman, Süleymaniye Kütüphanesinde Bulunan Yazma Tefsirler (Metod ve Kaynakları), İstanbul, 2002, s. 219.

10 Âgâ Büzürg-i Tahrânî, ez-Zerîa 'ilâ Tesânîfi'ş-Şîa ', Beyrut, ts. III/ 415.

11 Kâşânî, Tevîlâtül-Kurân, Amasya Beyazıt İl Halk Kütüphanesi, arşiv no: 05 Ba 26. Müfessirin diğer isimlendirmeleri için bk. Katip Çelebi, Keşfüzzünûn, I/107, 266, 336; Bağdadî, İsmail Paşa, Hediyyetü'l-Ârifinn, Esmâü'l-Müellfîn ve Âsâru'I-Musannifîn, İstanbul, 1951, I/567;Brockelmann, Carl, Geschichte Der Arabischen Litteratur Ester Suplementend (GAL) Leiden, 1938, II/280; Bilmen, Ömer Nasuhi, Büyük Tefsir Tarihi, (Tabakâtü'l-Müfessirîn), Ankara, ts., Il/428; Molla ibrahimoğlu, Yazma Tefsirler, s. 219.

12 Bk. Kâşânî, Hakâiku't-Te'vîl fî Dekâikı't-Tenzîl, Süleymaniye ktp. Fatih nr: 113; ayr. bk. Alkış, “Sermediyet ve Abdurrezzâk-ı Kāşânî",s. 208; Ergül, "Abdurrezzâk Kāşânî” , s. 94; Kaya, Kemâlüddîn Abdürrezzâk Kâşânî, s. 93. 
biyle13 bu şehirde doğmuş olması büyük olasılıktır. ${ }^{14}$

Kâşânî'nin hayatı hakkında en geniş bilgi Abdurrahman el-Câmî'’nin Nefahâtü'l-Üns adlı eserinde bulunmaktadır. Bununla birlikte müfessirin Hakâiku'tTe'vîl ve onun muhtasarı olan Te'vîlâtü'I-Kur'an'ında, Letâifu'I-i'lâm ve Tuhfetü'linvân adlı eserlerinde yer yer hayatı hakkında bilgilere rastlanılmaktadır.

\section{1. Kâşânî'nin Yaşamış Olduğu Dönemde Siyasi ve Sosyal Yapı}

Abdürrezzâk Kâşânî, İlhanlı hükümdarlarından Olcaytu Han (ö. 716/1316) ve Ebû Said Bahadır Han (ö. 735/1335) dönemlerinde15 İran'da cibal taşrası olan Kum ile Isfahan arasında yer alan Kâşân'da yaşamış bir müfessirdir. ${ }^{16}$ Her iki hükümdar döneminde de ilme büyük önem verilmiş ve İlhanlıların son hükümdarı Ebû Said Bahadır Han (ö. 735/1335) döneminde bu çalışmalar İran sınırlarını aşarak çok sayıda âlim yetişmiştir. ${ }^{17}$ Abdürrezzâk Kâşânî de bu rahat ortamdan istifade etmiş, Olcaytu Han'ın seferlerinde bile yanından ayırmadığı dört şeyhinden biri olmuş, ${ }^{18 H a k a ̂ i k u ' t-T e ' v i ̂ l ~ f i ̂ ~ D e k a ̂ i k i ' t-T e n z i ̂ l ~ a d l ı ~ t e f s i r i n i ~ d e ~ O l c a y t u ~ H a n ~(o ̈ . ~}$ 716/1316) Ebû Saîd Han (ö. 735/1335)'ın veziri Reşîdüddîn Fadlullah b. Ebi'lHayr'a (ö. 718/1318) ithaf etmiştir. ${ }^{19}$ Ayrıca Ebû Saîd Han (ö. 735/1335)'ı övdügü Kasîdetân fî Medhi Üveys Bahadır Han adlı bir eser20 kaleme almıştır. Bu bilgilerden hareketle Olcaytu Han'ın hükümdarlık yaptığı 703/1034 ile 715/1316 yılları arasında Tebriz ve Sultaniye şehirlerinde yaşadığı anlaşılan Kâşânî'nin21 tasavvuf ve tefsir başta olmak üzere farklı dallarda otuz beş eser vermesinde dönemin bu yapısının etkisi büyütür.22

Kâşânî̀nin yaşamış olduğu dönemde, halkının Sünni ve Şii olmak üzere iki gruba ayrıldığı haricinde şehrin sosyal ve kültürel yapısı hakkında bilgi bulunma-

13 Cezerî, İzzeddin Ebu'l-Hasen b. Esîr, el-Lübâb fî Tehzîbi'l-Ensâb, Beyrut, ts., III/75-76; Sem ânî, Ebû Saîd Abdilkerîm b. Muhammed b. Mansûr et-Temîmî, el-Ensâb, tahk., Abdullah Ömer Bârûnî, Beyrut, $1988, \mathrm{Il} / 428$.

14 Kâşân, merkezi İran platosunda,deniz seviyesinden 945 m yükseklikte Isfahan'ı Tahran'a bağlayan karayolu üzerinde Isfahan'a üç günlük mesafede, Kum'a 12 fersah uzaklığında, kumaş, halı ve bakırcılıkla meşhur, İran 'in en güzel ve temiz şehirlerinden biri olup, bakırcılık, sırma ve gümüş işlemeli ipekliler, kadife kumaşlar ve altın, gümüş ile çelik işçiliği gibi sanatlar yaygındır. Kavun, incir ve akrepleriyle meşhurdur. bk. Hamevî, Şehâbuddîn Ebû Abdillah Yâkût, Mucemu'l-Buldân, Beyrut, 1977, IV/296-297; Kurtuluş, Rıza, “Kâşân”,DiA, Ankara, 2002, XXV/3-4; Huart, Cl., “Kâşân”M.E.B.i.A. İstanbul, 1997, Vl/404.

15 Uludağ, "Kâşânî Abdürrezzâk" , s. 5.

16 Uludağ, "Kâşânî Abdürrezzâk" , s. 5; Alkış, "Sermediyet ve Abdurrezzâk-ı Kāşânî",s. 208.

17 Bk. Togan, Zeki Velidi, Umûmî Türk Tarihine Giriş, İstanbul, 1981, s. 272g-272h; Yuvalı, Abdülkadir, "IIhanlılar",DiA, İstanbul, 1994, XXII/105- 107.

18 Togan, Umûmî Türk Tarihine Giriş, s. 372;Kaya, Kemâlüddîn Abdürrezzâk Kâşânî, s. 40.

19 Kâşanî, Hakâiku't-Te'vîl vr.1º ; ayr. bk. Kaya, Kemâlüddîn Abdürrezzâk Kâşânî, s. 40.

20 Kaya, Kemâlüddîn Abdürrezzâk Kâşânî, s. 41

21 Ergül, "Abdurrezzâk Kāşânî”, s. 95.

22 Kaya, Kemâlüddîn Abdürrezzâk Kâşânî, s. 37. 
maktadır.23 Müfessirin hayatının geneli hakkında olduğu gibi, benimsemiş olduğu mezhebi hakkında da net bir bilgi yoktur. Istılâhât-ı Sûfiyye ${ }^{24}$ adlı eserinde $\mathrm{Hz}$. Ebubekr'in Rasulullah'a en yakın kişi olduğunu ifade eden bir hadis nakletmesi sebebiye sünnî olduğunu düşünenler olduğu gibi, Tuhfetü'l-ihnvân'ında üç yerde Hz. Ali'den üç yerde "aleyhisselâm" diye bahsederek diğer üç imamı zikretmemesi de Şii olduğuna delil olarak gösterilmiştir.25 Muhammed Abduh (ö. 1323/1905)26ve Tahir b. Âşûr (ö. 1393/1973)27, Kâşânî’nin Batınî olduğunu ifade etmiştir. Şimdi konu ile ilgili tartışmaları değerlendirelim.

\subsubsection{Kâşânî̉nin Batınî Olduğu İddiası}

Gerek biyografi eserlerinde gerekse Kâşânî'nin eserlerinde müfessirin mezhebi konusunda bir bilgiye yer verilmemektedir. Kâşânî'nin batınî28 olduğu düşüncesine gelince, bu düşünceyi son dönem âlimleri belirtmekte olup, onlar da Kâşânî'nin bu görüşte ifade etmekle yetinip bu konuda somut delil getirmemektedirler. Kâşânî'nin hayatı ile ilgili bilgilere29 ve eserlerine bakıldığında yanlış olduğu kolaylıkla anlaşılacaktır. Kanaatimizce Te'vîlât'ta, Hz. Ali ve Cafer-i Sâdık'tan çok miktarda rivayette bulunulması, Kâşânî'nin Batınî olduğu düşüncesinin ana omurgasını teşkil etmektedir.Ayrıca, Ayrıca, Te'vîlât'tamehdiyyet, Ehli beyt ve hurufilik gibi işarî ve şiî anlayışların önem verdiği konuların ortak olması,30 müfessirin, dolayısıyla eserlerinin tam olarak tanınmaması ve de Kâşânî'nin Şiiliği devletin resmi

23 Kâşânî'nin yaşamış olduğu dönemde Ebû Said Bahadır Han (ö. 735/1335), babası Olcaytu Han (ö. 716/1316) zamanında benimsenen Şiiliği terk ederek Sünnîliğe geçmiştir. Bk. Yuvalı, "Ebû Saîd Bahâdır Hân", DiA, İstanbul, 1994, X/219.

24 Kâşanî, Istılâhât-ı Sûfiyye, tahk.Abdülâl Şâhîn, Dâru'I-Menâr, 1992, s. 157; ayr. bk. Kâşânî, Şerhu Fusûsi'l-Hikem, Matbaatu'l-Meymene, Mısır, 1321, s. 75; Kâşânî, Te'vîlât, III/185, 208; Delillerine daha sonra değinileceği üzere Kâşânî'nin, İbn Arabî'ye nispetle Tefsîri'ş-Şeyhi'l-Ekber adıyla basılan Te'vîlât'ı noktasındaki bu yanlışı sürdürmemek için çalışmamızda Tefsîri'ş-Şeyhi'l-Ekber adıyla 1313 Hasan Halebî baskısını kullandığımız bu eseri, dipnotta Kâşânî'ye izafeten Te'vîlât şeklinde belirteceğiz. İkinci bir husus, eserin birinci cildi 360. sayfadan itibaren tekrar baştan numaralandırıldığı için, bu sayfadan sonraki alıntıları dipnotta c. 1 (2) şeklinde belirteceğiz.

25 Uludağ, "Kâşânî Abdürrezzâk", s. 5

26 Reşid Rıza, Tefsîr-u Kur'âni'l-Hakîm, Dâru'l-Menâr, Kahire, 1947, I/18.

27 ibn Âşûr, Muhammed et-Tâhir, et-Tahrîr ve't-Tenvîr, Tunus, 1984, I/34; Uludağ, Kadı Nurullah Şüsteri ve Âga Büzürgi Tahranî̀nin de Kâşânî'nin batınî olduğunu ifade ettiklerini belirtmişse de bk. Uludağ, "Kâşânî Abdürrezzâk" , s. 5, biz iki müellifin eserlerinde böyle bir bilgiye rastlamadık. Aksine her iki müellif de Kâşânî'ni bir sûfi olduğunu ifade etmektedir. Bk. Nurullah Şüsteri, Mecâlisü'l-Mü'minîn, Tahran, 1365; II/514-515; Âga Büzürgi Tahranî, ez-Zerîa ilâ Teşânîfi'ş-Şerîa, Beyrut, ts., II/122; III/308, 414-415.

28 Batınilik, genelde, her zahirin bir batını olduğu ve her nassın bir tevili bulunduğunu, bunu da sadece Tanrı tarafından belirlenmiş veya O'nunla ilişkisi olan masum bir imamın bilebileceğini iddia eden gruplara verilen isim olmakla birlikte özelde İmamiye Şi'asının bir kolu olarak değerlendirilir. Batiniler sistemlerini yedi esas üzerine oturtmuşlardır. Konu hakkında ayrıntılı bilgi için bk. İlhan, Avni, "Bâtıniyye" DiA., İstanbul, 1994, l/191-194.

29 Kâşânî'nin hayatı hakkında bilgi veren eserlerde onun hem zahir hem de batıni ilimleri cem etmiş bir mutasavvıf olduğu bilgisine yer verilir. Bk. Udnerevî, Tabakâtu'l-Müfessirîn, s. 271; Bağdadî, Hediyyetü'l-Ârifîn, I/567; Brockellman, Sup.,II/280; Bilmen, Büyük Tefsir Tarihi, II/428.

30 Konu hakkında ayrıntılı bilgi için bk. Öztürk, Mustafa, Kur'an ve Aşırı Yorum, Ankara Okulu Yay., 3. Baskı, Ankara, 2014, ss. 470-492), 
mezhebi yapan Olcaytu'nun yanından ayırmadığı dört şeyhinden biri olması da bu düşünceye sebep olan diğer unsurlardır. ${ }^{31}$

İlk olarak müfessirin eserleri arasında da batıni düşüncesine çağıran bir eser bulunmadığı gibi tam aksine Kâşânî, Te'vîlât'ta açıkça Batınîlerin düşüncelerine karşı çıkmaktadır. 32 Müfessir, hayatı hakkında bilgi verilen eserlerde zahir ve bâtınilimlerini cem etmiş bir arif/şeyh olarak takdim edilir. ${ }^{33}$ Ayrıca -ileride değinileceği üzere- Kâşânî'nin hocalarının arasında batınî düşünceye sahip biri bulunmadığı gibi hepsi de tasavvuf ile bağlantılı kişilerdir. Yine eserlerinin arasında Istılâhât-ı Sûfiyye, Letâifu'l-I'lâm, Şerhu Fusûsi'l-Hikem, Tuhfetü'l-Ihvân gibi çok sayıda tasavvufa dair eserin bulunması ve Hakâiku't-Te'vîl'in bir bölümünü de işaret yöntemine dair görüşlerin oluşturması ve Te'vîlât'ta ağırlıklı olarak vahdeti vücutekseninde görüşlere yer verilmesi ve Te'vîlât'ta Hz. Peygamber için “Ârifi Muhakkık" tabirini kullanmasının yanısıra ${ }^{34}$ mutasavviflardan nakilde bulunup 35 tasavvuf, mutasavvıfın tanımı ve şartları ile çeşitli tasavvufî terimlere değinmesi36 onun sufiolduğunu açıkça ortaya koymaktadır. Ayrıca müfessirin Alâüddevle Simnânî'ye yazdığı mektuptaki tasavvufî ifadelerden de onun sufi olduğu sonucuna ulaşılmaktadır. ${ }^{37}$

Yine, Kâşânî'nin, Hakâiku't-Te'vîl adlı tefsirini lüğat, i râb, me 'ânî, beyan, tefsir ve te'vîl olmak üzere beş bölüm halinde kaleme alması ve bu eserin işari yorumlarının eserin sadece beşte birlik bölümünü oluşturması ile38 sufilerin ıstılahı ile kaleme aldığı bir eser olarak nitelediği39 işarî bir tefsir olmasına rağmen Te'vîlât'ta zahiri yorumlara yer verilmiş olması da bu hususu desteklemektedir.

Batınilerin temel esası üzerinden Te'vîlât'ı incelediğimizde, Batıniler, bilgi konusunda masum bir imamın gerekliliğini savunurken, Kâşânî, ilmi, Allah'ın verdiğini ifade eder. ${ }^{40}$ Batıniler, Tanrının imama zuhur ettiğini kabul ederlerken, Kâşânî, vahdeti vücut düşüncesini savunur. Ayrıca Batıniler, Hz. Peygamberin tüm mesajı tebliğ etmediğini belirtirken, Kaşanî, her peygamberin mesajını eksiksiz tebliğ ettiğini ifade eder. ${ }^{41}$ Batıniler alemin ebediliğini savunurken, Kâşânî, alemin fani ol-

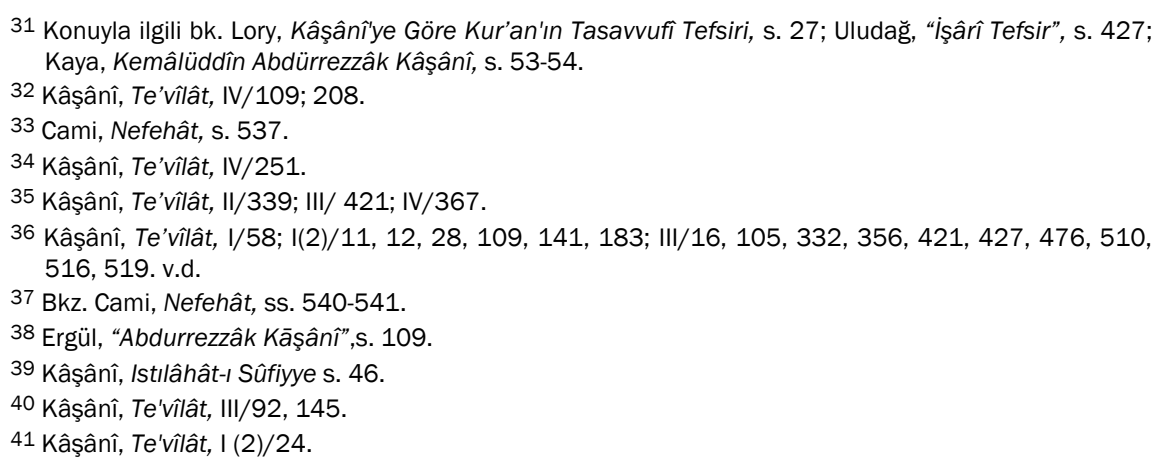


duğunu ifade eder.42 Batiniler, nassların sorumluluğunun sadece avam tabakası için geçerli olduğunu belirtirken, Kâşânî, her insanın sorumluluğunun eşit olduğunu belirtir. ${ }^{43}$ Batıniler, Hz. Peygamberin döneceğini ve bu dönüşün Hz. Ali tarafından gerçekleştirileceğini savunurken, Kâşânî, Hz. Peygamberin dönmeyeceğini, yine Hz. Ali'den aktardığı bir rivayetle destekler.44 Ayrıca, Batınileri savundukları takiyye esası, Te'vîlât'ta yer almamaktadır.

Son olarak Kâşânî, Şia'nın bir kolu olan bâtıniyeden farklı düşünmektedir. Bilindiği gibi Şia, hilafetin Hz. Ali'nin hakkı olduğunu, ilk üç halifenin ise bu vazifeyi gasp ettiği ve de Hulefâ-i Râşidindendaha fazla hilafete layık gördükleri imamlarının masum ve peygamberler gibi Allah ile irtibat halinde oldukları görüşündedir.45Kâşânî ise Şerhu Fusûsi'l-Hikem'de Hz. Peygamber'den sonra göreve gelen halifeler arasında böyle bir ayrıma gitmediği gibi, hepsinin hilafetinin makbul olduğunu ve tümünün Rasûlullah'ın yolundan gittikleri için verdiği kararların $\mathrm{Hz}$. Peygamberin kararı gibi uyulması zorunlu hükümler olduğunu, 46 bununla birlikte halifelerin hatadan da beri olmadıklarını 47 bu durumun da halifelerin peygamberler gibi ilahi mesajla bağlantılı olmadıklarını gösterdiğini, verdikleri kararları $\mathrm{Hz}$. Peygamberden menkul haberlere istinaden verdiklerini48 belirtir. Kâşânî ayrıca İbn Arabî'nin, Fusûsu'l-Hikem'deki Hz. Peygamberin, vefatından sonra göreve gelecek halifeyi tayin etmediği şeklindeki49 görüşüne de itiraz etmemiştir. Dolayısıyla Kâşânî'nin, Şia'nın, hilafetine karşı çıktığı üç halifeden $\mathrm{Hz}$. Ebubekr50 ve Hz. Ömer51 için övgü ifade eden ifadelere itiraz etmemiş olması ve Ebubekr'i öven hadis nakletmesinin yanı sıra52 onu “Sıddıkların başı" ve Hz. Peygamber'den sonra en değerli insan olarak nitelemesi53, ve onun hakkında "emîru'l-Mü'minîn ve radiyallahu anh" ifadelerini kullanması ${ }^{54}$ ve Hakâiku't-Te'vîl'de Hz. Ömer hakkında “emîru'l-Mü'minîn ve radiyallahu anh" ifadelerini kullanması55 ile Te'vîlât'ta kendisinden rivayette bulunması ${ }^{56}$ onun sünni olduğu görüşünü desteklemektedir. ${ }^{57}$

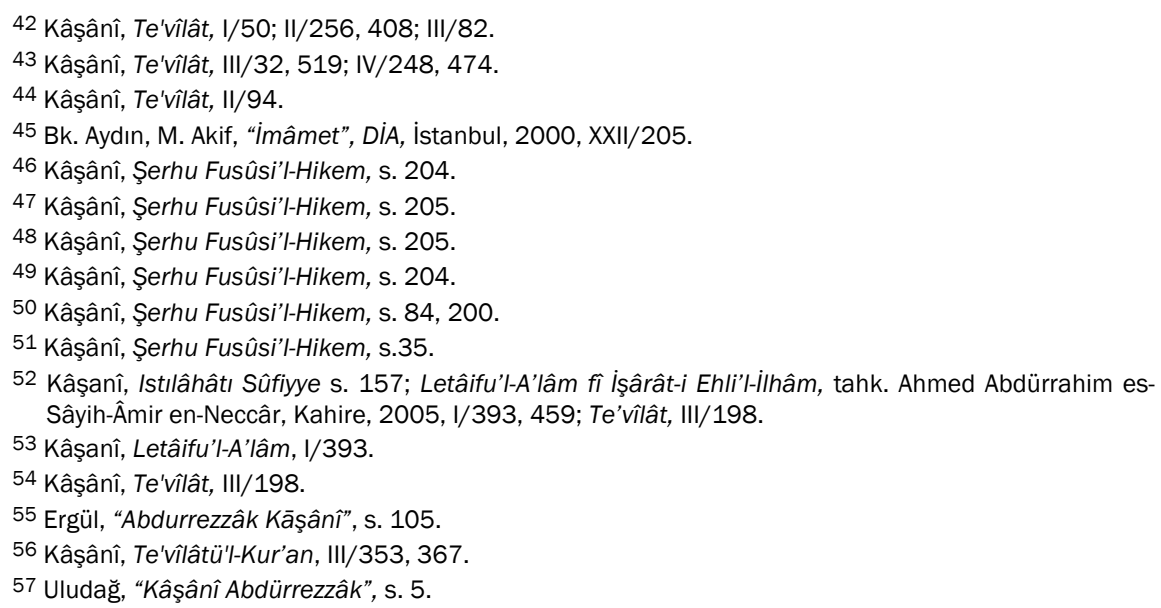




\subsection{Kâşânî́nin Hocaları}

Kâşânî, eserlerinde iki hocasından bahsetmektedir. Hocaları hakkındaki diğer bilgiler ise Molla Cami'nin Nefehâtü'I-Üns'ü başta olmak üzere tabakat kitaplarından menkuldür. Molla Cami'nin eserinde yer verdiği Kâşânî̀nin, Âlâuddevle esSimnânî, (ö. 736/1336)'ye yazmış olduğu mektupta ismini verdiği hocaların yanı sıra birçok âlimin sohbetinde bulunduğunu belirtmektedir. ${ }^{58}$ Kâşânî, Âlâuddevle es-Simnânî, hariç bütün hocalarıyla görüşmüştür. Bununla birlikte hocalarından ne kadar süreyle ve hangi konularda eğitim aldığı bilgileri mevcut olmayıp eserlerinde verdiği bilgiye dayanarak en çok Nûreddîn en-Natanzî (ö. 699/1300)'den ders aldığı ve ondan etkilendiği anlaşılmaktadır. Sührevî şeyhlerinden Abdüssamed b. Ali en-Natanzî(ö. 699/1300)'den hırka giyen Kâşânî'nin tarikat silsilesi Abdüssamed en-Natanzî, Necîbüddin b. Buzguş (ö. 716/1316) vasıtasıyla 'Avârifü'l-Ma‘ârif müellifi Şihâbeddin es-Sühreverdî (ö. 632/1234)'ye ulaşmaktadır.59 Müfessirin hocaları şunlardır:

2.2.1. Kardeş olan Şeyh Nasîruddîn Muhammed et-Tûsî (ö. 672/1272) ${ }^{60}$ ve Şeyh Kutbeddîn eş-Şirâzî (ö. 710/1311) ${ }^{61}$

\subsubsection{Mevlânâ Nûreddîn Asîleddîn (ö. 685/1286) ${ }^{62}$}

2.2.3. Mevlânâ Şemseddîn el-Kîşî (ö. 694/1295) 63

Müfessir, Hakâiku't-Te'vîl adlı tefsirinin mukaddimesinde el-Kîşî (ö. 694/1295)'den bahsetmekle birlikte hocası Natanzî'den menkul bu ifadelerde, el-Kîşînnin, Kâşânî'ye hocalık yaptığına dair ifadeler yoktur. ${ }^{64}$ Bununla birlikte Abdurrahman Câmî'nin eserine aldığı mektupta, Kâşânî, el-Kîşî’nin sohbetinde bulunduğunu ve Natanzî'nin, Kîşî için, "Bu asırda onun mislitarîkı ma 'rifette yoktur."dediğini belirtmektedir. 65

\subsubsection{Mevla Nûreddîn Abdüssamed b. Ali en-Natanzî (ö. 699/1300)66}

Kâşânî, zahirî ilimlerdeki en büyük hocası ve manevî ilimlerdeki en büyük şeyhi olan Natanzî'den, iki eserinde bahsetmektedir. Kâşânî'nin verdiği bilgiye göre Natanzî, kendisini tasavvuftan önce hadis, tefsir gibi zahiri ilimleri öğrenmeye

\footnotetext{
58 Cami, Nefehât, s. 540-541.

59 Cami, Nefehât, s. 535; Uludağ, "Kâşânî Abdürrezzâk",s. 5.

60 Cami, Nefehât, s. 541; Hayatı için bk. Togan, Umumi Türk Tarihine Giriş, s. 223, 273, 282; Şirinov, Agil, “Tûsî, Nasîruddîn”,DiA, Ankara, 2012, XXXXI/437-441.

61 Cami, Nefehât, s. 541; Hayatı için bk. Togan, Umumi Türk Tarihine Giriş, s. 282. Kâtip Çelebi, Keşfüzzunûn, I/367-368; Bağdadî, Hediyyetü'l-Ârifîn, Il/406-407; Şerbetçi, Azmi, Kutbüddîn-i Şîrâzî", DiA, Ankara, 2002,XXVI/487-488.

62 Cami, Nefehât, s. 541; Hayatı için bk. Togan, Umumi Türk Tarihine Giriş, s. 282.

63 Cami, Nefehât, s. 541.

64 Kâşânî, Hakâiku't-Te'vîl vr. $1^{\text {b. }}$.

65 Cami, Nefehât, s. 540.

66 Cami, Nefehât, s. 534.
} 
yönlendirmiş67 ve Hakâiku't-Te'vîl adlı tefsirini yazmaya teşvik etmiştir.68 Kâşânî ikinci olarak da Te'vîlât'ta hocasından bahseder.69 Kâşânî'nin, hocası Natanzî'den sonra hiçbir şeyhe intisap etmediği ve üzüntüsünden yedi ay bir çölde halvete girdiği bilgisine yer verilir. 70

2.2.5. Zahîruddîn Abdurrahman b. Ali Buzkuş (ö. 716/1316) ${ }^{71}$

2.2.6. Nûreddîn Abdurrahmân el-lsferâînî (ö. 717/1317) 72

Kâşânî'nin 687/1288 yılında Hicaz dönüşü Bağdat'ta elIsferâînî'ninsohbetinde bulunduğu belirtilmiştir.73

2.2.7. Rukneddîn Âlâuddevle es-Simnânî, (ö. 736/1336)

İki âlim arasında sadece vahdeti vücut hakkında bir mektuplaşmanın olduğu bilgisi mevcuttur. ${ }^{74}$

Kâşânî'nin mezkûr mektupta zikredilen hocalarından Nûreddîn Abdurrahmân el-Isferâînînnin Bağdat, diğerlerinin ise Şiraz'da ikamet etmeleri sebebiyle bu iki şehre yolculuk ettiği anlaşılmaktadır. ${ }^{75}$ Kâşânî̀nin mezkûr mektubunda Arâisü'lBeyân müellifi Ruzbihân Baklî (ö. 606/1210) ile de görüştüğü belirtilse de ${ }^{76}$ her iki müfessirin yaşadığı dönem göz önüne alındığında sadece Nefehât'ta yer alan bu bilginin doğruluğu pek mümkün görünmemektedir.

\section{3. Kâşânî'nin Öğrencileri}

Kâşânî'nin öğrencileri hakkında eserlerde yeterli bilgi bulunmamaktadır. Bazı eserlerde Davud-u Kayserî'nin, Kâşânî̀nin öğrencisi olduğu bilgisine yer lir. ${ }^{77}$ Davud-u Kayserî, ibn Arabî'nin Fusûsu'l-Hikem'ine yazmış olduğu Matla'u Husûsi'l-Kelim fî Me‘ânî Fusûsil Hikem adlı şerhin mukaddimesinde kaderi ilahinin kendisini asrının eşsiz âlimi ve mevlâ olarak nitelediği Kâşânî'nin hizmetine sevk ettiğini belirterek, o esnada Abdürezzâk Kâşânî'nin huzurunda, tahsili kemal için gayret sarfeden ve esrarı ilahiyyeyi öğrenmek isteyen bir grup öğrencinin Fusûsu'lHikem'i okumaya başladıklarını ifade etmektedir. ${ }^{78}$ Bu ifadeler, Kâşânî'nin ismini

\footnotetext{
67 Kâşânî, Hakâiku't-Te'vîl vr.1; ayr bk. Cami, Nefehât, s. 540.

68 Kâşânî, Hakâiku't-Te'vîl vr.1; ayr. bk. Ergül, “Abdürrezzâk Kâşânî”, s. 99.

69 Kâşânî, Te'vîlât, III/494.

70 Cami, Nefehât, s. 541; hayatı için bk. Cami, Nefehât, s. 534-535.

71 Cami, Nefehât, s. 541; hayatı için bk. Cami, Nefehât, ss. 529-530, s. 535.

72 Cami, Nefehât, s. 541, 543; hayatı için bk. Cami, Nefehât, ss. 495-496.

73 Cami, Nefehât, s. 496.

74 Mektup için bk. Cami, Nefehât, s. 537-543; hayatı için bk. Bağdadî, Hediyyetü'l-Ârifîn, I/108; Cami, Nefehât, s. 496-500.

75 Alkış, “Sermediyet ve Abdurrezzâk-ı Kāşânî",s. 210.

76 Cami, Nefehât, s. 541.

77 Kâtip Çelebi, Keşfüzzünûn,II/1038, 1720; Togan, Umumi Türk Tarihine Giriş, 372, Bayraktar, Mehmet, “Dâvûd-i Kayserî",DiA, İstanbul, 1994, IX/ 32-33.

78 Davud el-Kayserî, Mahmûd b. Muhammed, Matla‘u Husûsi'l-Kilem fî Ma‘ânî Fusûsi'l-Hikem, Kral Suud Üniversitesi Ktp, nu: 2950z/189gm, vr. ${ }^{2}$;Bu eserin çeşitli baskıları yapıımıştır. Mirza Muham-
} 
bilemediğimiz birçok öğrenci yetiştirdiğini de göstermektedir.

Ayrıca, Davud-u Kayserî'nin hocası Kâşânî gibi İbn Arabî̀nin Fusûsu'lHikem'ini şerh etmesi79, bu esere Kâşânî'nin Şerhu Fusûsi'l-Hikem'inin kaynaklık etmiş olması ${ }^{80}$, ve Kâşânî'nin Te'vîlât'ının başındaki besmele tefsirini şerh etmesi,81 vahdeti vücut görüşünde Kâşânî ile aynı çizgide olması ve tarikat silsilesinin Kâşânî'ye dayanması82 bu hususu desteklemektedir. Bu birlikteliğin Tebriz'de gerçekleşmiş olması muhtemeldir. Zira iki âlim Reb i Reşidî hankahı'ndatanışmış ve uzun süre Fusûs veTe'vîlât okumuştur. ${ }^{83}$ Rukneddin eş-Şîrâzi'nin Kâşânî'ye talebelik yaptığı ve de bunu Nusûsu'l-Husûs fî Tercümeti'l-Fusûs adlı eserinde belirttiği bilgisi de mevcuttur. 84

\section{KÂŞÂNî'NIN ILMî KişiLiĞi}

Daha önce de belirttiğimiz gibi Kâşânî'nin yetişmesindeki en önemli iki hocası Nureddîn Natanzî (ö. 699/1300) ve Şemseddîn el-Kîşî (ö. 694/1295)'dir. Yazdığı eserlerin sayısı ve çeşitliliği bakımından iyi bir eğitim aldığı anlaşılan Kâşânî, ibn Arabî'nin ortaya koymuş olduğu vahdeti vücut anlayışını sistematize eden ve Fusûsu'l-Hikem'in anlaşılmasına vesile olan kişi olarak ifade edilir. ${ }^{85}$ Kâşânî, Misbâhü'l-Hidâye müellifi İzzettin el-Kâşî6 ile birlikte şeyhleri Abdüssamed'in yanı sıra Isfahan, Kâşân, Sâve, Şîraz ve Bağdat'taki diğer Sühreverdî şeyhlerinin sohbet meclislerine katılarak onlardan da feyiz almış, tasavvufî görüşleri bu muhitte oluşmuştur. İbn Arabî'nin eserlerine ise şeyhinin ölümünden sonra ilgi duymaya başladığı anlaşıımaktadır. ${ }^{87}$ Tasavvuf ve tefsir başta olmak üzere çeşitli dallarda birçok eseri bulunan Kâşânî̀nin, eserlerinin çoğunun ömrünün son on yılında Reb i Reşîdî hankahı'nda yazdığı belirtilir.88

\subsection{Kâşânî́nin Eserleri}

Tespit edildiğine göre Kâşânî̀nin tefsir ve tasavvuf başta olmak üzere otuz $\rightarrow \rightarrow$

med Şîrâzî'nin tahkikiyle Bombay'da 1300 yılında, Asım Ibrahim el-Keyyâlî'nin tahkikiyle Dâru'lKütübi'lïlmiyyede basılmıştır.

79 Davud el-Kayserî,Şerhü Fusûsil-Hikem, Milî Ktp. Çankırı İ Halk Ktp. 18 HK 222.

80 Kâtip Çelebi, Keşfüzzunûn, II/1038.

81 Davud el-Kayserî,Şerhu Besmele bi’s-Sûreti'n-Nev 'iyyeti'l-Insâniyye,Süleymaniye Ktp., Esad Efndi, nr. 1693/16; ayr. bk. Bayraktar, "Dâvûd-i Kayserî”, s. 35.

82 Bayraktar, “Dâvûd-i Kayserî”, s. 33.

83 Alkış, "Sermediyet ve Abdurrezzâk-ı Kāşânî", s. 211; ayr. bk. Karadaş, Cağfer, "Dâvûd-i Kayserî ve Genel Hatlarıyla Düşüncesi”,Uludağ Ü.İ.F.D., 2006 c. 15, sa. 2, ss. 1-18; Kayserî’nin hayatı için bk. Kâtip Çelebi, Keşfüzzünûn, II/1720; Bağdâdî,Hediyyetü'l-Ârifîn, I/361; Serkis, Mu 'cemu'l-Matbûa, II/1537; Bayraktar bu birlikteliğin Save şehrinde olabileceğini belirtir. Bayraktar, "Dâvûd-i Kayserî", s. 32.

84 Ergül, “Abdurrezzâk Kāşânî”, s. 101; Hayatı için bk. Kâtip Çelebi, Keşfüzzünûn, II/1264.

85 Izutsu, s. 20; ayr. bk. Ergül, “Abdurrezzâk Kāşânî”, s. 103.

86 Hayatı için bk. Cami, Nefehât, s. 535-536.

87 Uludağ, "Kâşânî Abdürrezzâk", s. 5; ayr. bk. Cami, Nefehât, s. 535.

88 Alkış, "Sermediyet ve Abdurrezzâk-ı Kāşânî”, s. 212; Ergül, “Abdurrezzâk Kāşânî”, s. 96. 
beş eseri bulunmaktadır. ${ }^{89}$ Bunların çoğunluğu tasavvufa dair olup eserlerinin büyük bir kısmını risaleler oluşturmaktadır. Müfessirin öne çıkan ve basılan eserleri şunlardır:

\subsubsection{Hakâiku't-Te'vîl fî Dekâikı't-Tenzîl}

Ayetlerin lüğat, i'râb, me 'ânî, beyan, tefsir ve te'vîl olmak üzere beş bölüm halinde kaleme alındığı tefsirin ilk cildi Necmettin Ergül tarafından 2002 yılında doktora tezi olarak tahkik edilmiştir.

\subsubsection{Te'vîlâtü'I-Kur'an}

Çalışmamızın asıl konusunu oluşturan bu eser, Kâşânî'nin Hakâiku't-Te'vîll adlı tefsirinin te'vîl bölümünün bir araya getirilmesiyle oluşturulmuştur. Eser, 1283, 1300, 1317 yıllarında Kahire'de, 1968 ve 1978 yıllarında ise Beyrut'ta İbn Arabî'ye nispetle Tefsîri Şeyhi'l-Ekber adıyla basılmış ve bu isimle meşhur olmuştur. ${ }^{90} \mathrm{Bu}$ eserle ilgili ileride ayrıntılı bilgi verilecektir.

\subsubsection{Letâifu'I-A 'lâm filişârâti Ehli'I-ihâm}

Tasavvufî ıstılahlara dair yazılan en geniş eser kabul edilen eser, Saîd Abdülfettâh'ın tahkikiyle 1996 yılında Kahire'de, Mecid Hadîzade'nin tahkikiyle 1421/2000 yılında Tahran'da, Ahmed Abdürrahim es-Sâyih ve arkadaşlarının tahkikiyle 2005 yılında Kahire'de basılmıştır. Ayrıca Ekrem Demirli tarafından Tasavvuf Sözlüğü adıyla tercüme edilmiş ve 2004 yııında İstanbul'da basılmıştır.

\subsubsection{Istılâhât-ı Sûfiyye}

Beş yüz tasavvuf teriminin ebced hesabına göre açıklandığı tasavvuf sözlüğüdür. Kâşânî, bu eseri Şerhu Fusûsi'l-Hikem ve Te'vîlât'taki tasavvufi terimleri açıklamak için yazmıştır. ${ }^{91}$ 1981, 1992 yılında Kahire, 1995'te Şam'da basılmıştır. Eser Nabil Safwat tarafından Glossary of Sufi Technical Terms adıyla Ingilizceye çevrilmiş ve 1984, 1991 ve yıllarında Londra'da basılmıştır.Muhammed Hâcevî ise eseri, Ferheng-i Istılâhât-ı 'Irfân Tasavvuf adıyla Farsça'ya tercüme ederek 1372 yılında Tahran'da yayımlamıştır.

\subsubsection{Raşhu'z-Zulâl fî Şerhi'I-Elfâzi'I-Mütedâvile beyne Erbâbi'I-Ezvâk ve'I-Ahvâl}

Kâşânî'nin tasavvuf ıstılahına dair diğer bir sözlüğüdür. Eser Said Abdülfettah'ın tahkikiyle 1995 yılında Kahire'de basılmıştır.

\subsection{6. Şerhu Fusûsi'I-Hikem}

Kâşânî'nin İbn Arabî'nin Fusûsu'l-Hikem adlı eserine yazdığı şerhtir. İbn Arabî'nin vahdeti vücuda dair görüşlerinin anlaşılmasındaki en etkili ve güvenilir

\footnotetext{
89 Bu eserlerle ilgili ayrıntılı bilgi için bk. Ergül, "Abdurrezzâk Kāşânî", ss. 106-12; Kaya, Kemâlüddîn Abdürrezzâk Kâşânî, s. 57-68; Uludağ, "Kâşânî Abdürrezzâk", ss. 5-6.

90 Kaya, Kemâlüddîn Abdürrezzâk Kâşânî, s. 59.

91 Kâşânî, Istılâhâtı Sûfiyye, s. 46.
} 
şerhlerinden biri kabul edilir. 92 Bu eser 1303/1891, 1309/1897, 1321/1903 ve 1966 yıllarında Mısır'da basılmıştır.

\subsection{7. Şerhu Menâzili's-Sâirîn}

Ebû İsmail Abdullah Ensari el-Herevî'nintasavvuf ıstılahları hakkında yazdığı Menâzili's-Sâirîn adlı eserini şerhidir. Eser Ali Şirvânî'nin tahkikiyle 1373 yılında Tahran'da, Muhsin Bîdâr Fer'in tahkikiyle 1995 yılında Beyrut'ta basıımıştır.

\subsubsection{Tuhfetü'l-ihvân fî Hasâisi'l-Fityân}

Kâşânî'nin fütüvvet hakkında kaleme aldığı risalesidir. Eser Seyyid Muhammed Dâmâdî'nin tahkikiyle 1349/1929, 1369/1949 tarihlerinde Tahran'da Farsça olarak basılmıştır.

\subsubsection{Keşfü Vücûhi'l-Ğurr li Me' ânî Nazi'd-Dürr}

İbn Fârıd'ın Tâiyyetü'l-Kübra adlı eserinin şerhidir. Ahmed Ferîd el-Miziyâdî'nin tahkikiyle 2005 yılında Lübnan'da basılmıştır.

\subsubsection{Risâle fi'l-Kazâ ve'I-Kader}

Kâşânî'nin kaza ve kadere dair yazmış olduğu bir risale olup Stanislav Guyard tarafından Traité De La Prédestination Et Du Libre Arbitre adıyla Fransızcaya çevrilmiş ve 1875 ve 1819 'da Paris'te yayınlanmıştır.

\section{KÂŞÂNÎ'NIN VEFATI}

Kâşânî'nin vefat tarihinde de intilaf edilmiştir. Bazen bu intilaf aynı kişinin verdiği tarihte de olabilmektedir. Örneğin Brockellman 730/1330, 735/1335 ve 736/1336;93 Nuveyhid, 720, 730 ve 735 tarihlerini vermektedir.94 Bağdadî ise $730 / 1330$ ve $735 / 1335$ tarihlerini95 zikretmiştir. 735/1335 tarihini verenlerin, müellifi aynı tarihte vefat eden İzzeddin Mahmud Kâşânî ile karıştırmaları muhtemeldir. Kâtip Çelebi,96 Udneveri97 ve Rıza Kehhale,98 Zirikli,99 Kâşânî'nin vefat tarihi olarak 730/1330 tarihini verir. Macdonald, Kâşânî'nin Alâüddevle ile mektuplaşması nedeniyle100 Süleyman Mollaibrahimoğlu, Hakâiku't-Te'vîli 729 yılında bi-

\footnotetext{
92 Afifi, A.E, Muhyiddîn ibnü'l-Arabî’nin TasavvufFelsefesi, (ter. Mehmet Dağ), Ankara Ü. İ.F. Yay. Ankara, ts. s. 12; Uludağ, "Kâşânî Abdürrezzâk", s. 6; Ergül, "Abdurrezzâk Kāşânî", s. 112.

93 Brockellman, Sup., 280.

94 Nuveyhid, Mu 'cemu'l-Müfessirîn, s. 281.

95 Bağdadî, Hediyyetü'l-Ârifin, I/567.

96 Kâtip Çelebi başka bir yerde verdiği 887 tarihi ile müfessiri Matla 'u's-Sa'deyn müellifi ile karıştırmıştır. Kâtip Çelebi Keşfüzzünûn, 1/336.

97 Udnerevî, Tabakâtu'l-Müfessirîn, s. 139.

98 Kehhâle, Ömer Rıza, Mu'cemu'I-Müellifin Terâcim-i Musannifi'l-Kütübi'I-Arabiyye, Beyrut, 1993,I/138.

99 Zirikli, Hayrettin, el-A'lâm Kâmûs-u Terâcim li Eşher'ir-Ricâl ve'n-Nisâ mine'I-Arabi ve'l-Müsta'ribîn, Beyrut, 1997, III/350.

100 Macdonald, “Abdürrezzâk Kâşânî”, s. 106.
} 
tirmesi sebebiyle,101 730 tarihinin doğru olduğunu belirtir. Abdürrahim Alkış ise, Mücmelü’t-Tevârîh yazarı Fasîh-i Hafî (ö. 849)'nin zikrettiği 3 Muharrem 736 tarihinin ayrıntılı içermesi ve de müellifin o bölgeyi iyi bilmesi sebebiyle daha muteber kabul etmektedir.102

Kâşânî'nin nerede vefat ettiği ve mezarının nerede olduğu ile ilişkin olarak son dönemde kaleme alınmış bazı eserlerde, müfessirin Kâşân'da vefat ettiği ve mezarının burada bulunduğu bilgisine yer verilmekle birlikte ${ }^{103}$ Kâşânî'nin hayatı hakkında bilgi veren biyografi eserlerinde böyle bir bilgi bulunmamaktadır.

\section{KÂŞÂNî'NIN TE'VÎLÂTÜ'L-KUR'ANI'L-HAKÎM'i, TEFSIR ILMINDEKI YERI VE TEFSIR METODU}

Bu başlık altında Te'vîlât'ın Kâşânî'ye aidiyeti, tefsir ilmindeki yeri ve tefsir metodolojisine değinilecektir.

\section{1. Te'vîlât'ın Kâşânî'ye Aidiyeti ve Tefsir Tarihindeki Yeri}

Te'vîlâtu'l-Kur'an, i̇bnu'l-Arabî'ye izâfe edilerek Tefsîr-i Şeyh-i Ekber adıyla basıldığı için bu isimle meşhur olan ve ayetlerin işarî tefsir metoduna göre tefsir edildiği bir eserdir. Kâşânî bu eseri, te'vîl hakikatleri hususunda Hakâiku'tTe'vîl'inmuhtasarı olarak yazmıştır. Kâşânî'nin, mezkûr eserin mukaddimesinde verdiği bilgiye göre, önce Hakâiku't-Te'vîl tertibinde Kehf suresini yazdığl; ancak daha sonra bunu bitirmeden Te'vîlât'ı tamamladığını, daha sonra tekrar Hakâiku'tTe'vîl adlı eserine dönerek tefsirini tamamladığını ifade etmektedir. ${ }^{104}$

Eserin İbnü'l-Arabî̀ye izafe edilerek basılmasından 81 yıl sonra 1948 yılında Kahire'de Daru'I-Kütübi'l-Mısriyye'de basılan Ahmet Teymur Paşa'nın Fihrisü Hizâneti't-Teymûriyye eserinde bu Te'vîlât'ın Kâşânî'ye ait olduğu belirtilmesine rağmen ${ }^{105}$ en son 2006 yılında Dâru'I-Kütübi'I-IImiyye'de yapılan baskısında eser yine İbnü'l-Arabî'nin tefsiri adıyla basılmıştır. Ayrıca Te'vîlâtü'l-Kur'an,106 Te'vîlü'lÂyât,107 Te'vîlâtı Kâşâniyye108adıyla bilinen eserin tam ismi Te'vîlâtü'l-Kur'ani'lHakîm'dir. 109 ỉbn Arabî'ye değil, Kâşânî̀ye aidiyeti birçok açıdan ispat edilmiştir.

a. Kâşânî, Hakâiku't-Te'vîl,110/stılâhâtı Sûfiyye111 veŞerhu Fusûsi'l-

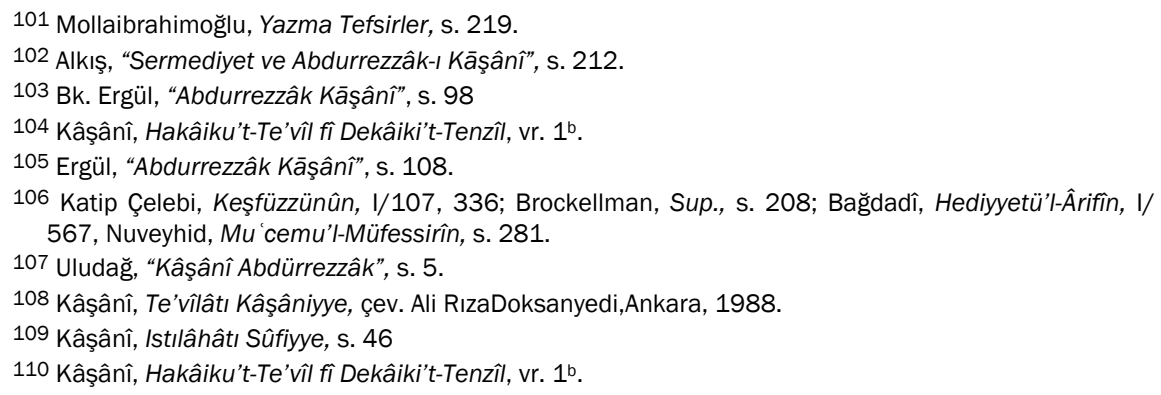


Hikem'inde112 Te'vîlâtü'l-Kur'ani'I-Hakîm adında Kur'an'a dair bir eser yazdığını belirtmektedir.

b. Te'vîlât'ın yazmaları İbn Arabî'ye değil, Kâşânî'ye nispet edilmektedir.113

c. Müfessirin hayatı hakkında bilgi veren eserlerde Te'vîlât, Kâşânî'ye nisbet edilmektedir. ${ }^{114}$

d. Tefsirin diğer dillere çevirileri de Kâşânî’ye nispetle yapılmıştır. Eser Ali Rıza Doksanyedi tarafından Te'vîlâtı Kâşâniyye adıyla Türkçe'ye çevrilmiş ve 1987 ve 1988 yılında üç cilt halinde Ankara'da basılmıştır. Tafsīr al-Kāshānī adıyla ilk on sekiz sure Royal Ali Beyt İslami Düşünce Enstitüsü tarafından İngilizceye çevrilmiştir.

e. Te'vîlât'ın, Kâşânî'ye ait olduğu son dönemde yapılan çalışmalarda da dile getirilmiştir.115 Muhammed ez-Zehebî (ö. 1397/1977), eserin Kâşânî̀ye aidiyetini ispat sadedinde kaleme aldığı Tefsîru ibn Arabî li'l-Kur'ân -Hakîkatuhû ve Hataruh isimli çalışma Medine el-Câmiati'l-İslâmiyye dergisinde yayımlanmıştır.

f. Müellifin iki eserinde bahsetmiş olduğu Abdüssamed b. Ali en-Natanzî (ö. 699/1300) ve es-Saîd el-Kîşî (ö. 694/1295)'nin kendilerinden önce yaşayan ve 638/1240 yılında vefat İbn Arabî'ye hocalık yapmış olmaları tarihen mümkün görünmemektedir.116

g. Kâşânî Te'vîlât'ta bulunmuş olduğu Ebîverd şehrinden117 bahsetmektedir. ${ }^{118}$ Süleyman Ateş bu ifadelere dayanarak İbn Arabî'nin Ebîverd tarafına gittiğini gösteren hiçbir delilin bulunmadığını, dolayısıyla bu olayı anlatanın Ebîverd hadisesini bilen Kâşânî'nin olduğunu belirtmektedir.119

h. İsmail Hakkı Bursevî'nin Rûhu'l-Beyân ve Âlûsî'nin Rûhul'Me 'ânîadlı tefsirlerde Te'vîlât'tanistifade edilmesi, günümüzden yaklaşık üç yüz yıl önce bu durumun müfessirlerce teyit edildiğini ve daha sonra bu hakikatin değiştirildiğini gös-

$\rightarrow \rightarrow$

111 Kâşânî, Istılâhâtı Sûfiyye, s. 46.

112 Kâşânî, Şerhu Fusûsi'l-Hikem, s. 262.

113 Bk. Milli Kütüphane -Ankara, Samsun Il Halk Kütüphanesi, arşiv no: 55 Hk 928; Kastamonu İ Halk Kütüphanesi arşiv no: 37 Hk 929; Selimiye Yazma Eser Kütüphanesi, arşiv no: 22 Sel 278; Edirne Selimiye Yazma Eser Kütüphanesi Selimiye Yazma Eser Kütüphanesi, arşiv no: 37 Hk 929; Amasya Beyazıt il Halk Kütüphanesi koll, arşiv no: 05 Ba 26.

114 Kâtip Çelebi, Keşfüzzünûn I/336; Cami, Nefehât,s. 537; Udnerevî, Tabakâtu'l-Müfessirîn, s. 271; Zirikli, el-A'lâm III/350; Bağdadî, Hediyyetü'l-Ârifin, I/567; Brockellman, Sup., 280; Âgâ Büzürg-i Tahrânî, ez-Zerîa, II/122, III/308; Nurullah Şüsteri, Mecâlis, II/515; Bilmen, Büyük Tefsir Tarihi, II/428; Kehhâle, Mu'cemu'l-Müellifîn, II/138.

115 Lory, Kâşânî'ye Göre Kur'an'ın Tasavvufi Tefsiri, s. 25; Zehebî, Muhammed Hüseyn et-Tefsîr ve'lMüfessirûn, Mektebetü Vehbe, Kahire, ts. Il/295-296; Uludağ, "iş̧ârî Tefsir", s. 427, Duman M. ZekiAltundağ Mustafa, "Hurûf-ı Mukattaa”,DiA, İstanbul, 1998, XVIII/405; Ergül, "Abdurrezzâk Kāşânî”, s. 107-108; Kaya, Kemâlüddîn Abdürrezzâk Kâşânî, s. 53-54; Ateş, s. 204.

116 Ayr. bk. Lory, Kâşânî'ye Göre Kur'an'ın Tasavvufî Tefsiri, s.26.

117 Horasan'da Serahs ve Nesâ arasında bulunan bu şehir hakkında bilgi için bk. Hamevî, Mu 'cemu'lBuldân, l/ 86.

118 Kâşânî, Te'vîlât, IV/74.

119 Ateş, İşârî Tefsir Okulu,ss. 204-205. 
termektedir. Bütün bu deliller bu eserin İbn Arabî'nindeğil, sufi Abdürrezzak Kâşânî'ye ait olduğunu desteklemektedir. ${ }^{120}$

Te'vîlât, tefsir tarihinde hak ettiği yeri alamamış olsa da kendisinden sonraki bazı işarî tefsirleri etkilemiştir. Bursevî'nin Rûhu'I-Beyân adlı tefsirinde ve -o kadar olmasa da- Âlûsî'nin Rûhul'Me ânî̉sinde Te'vîlât'tan nakillere rastlanılmaktadır. Temel kaynakları arasında Te'vîlât'ın zikredildiği121 Bursevî,Rûhu'l-Beyân tefsirinde -tespit edebildiğimiz kadarıyla- 143 yerde çoğunlukla "Kâşânî dedi ki:..." ifadesiyle Te'vîlât'tan nakilde bulunur. Âlûsî ise, iki yerde Te'vîlât'tan nakilde bulunur. Müfessir bir yerde القاشانىnisbesini kullanırken,122 bir yerde de عبد الرزاق الكاشى nisbesini kullanmaktadır. ${ }^{123}$ Son dönem müfessirlerinden Cemâleddin el-Kâsımî ise Mehâsinü't-Te'vîl adlı tefsirinde 240 yerde isim vererek Kâşânî'den nakilde bulunur.

\subsection{Tefsir Metodolojisi Açısından Te'vîlâtü'I-Kur'an}

Kâşânî'nin, Kur'an tilavetine devam ettiği ve manalarını düşündüğü sırada her ayetin altında görünen ve kalbine doğan farklı mana ve hakikatleri kayda geçirmek maksadıyla kaleme aldığını belirttiği Te'vîlât,,124 Kur'an'ın baştan sona Mushaf tertibine göre yazıımışişarî tefsiri olmakla birlikte, eserde tüm ayetler tefsir edilmemiştir. Tefsir edilen ayetlerin genelinde ise uzun izahlar yapılmamış, kimi zaman ayet bir veya birkaç kelime ile açıklanmıştır. Eserde çok miktarda zahirî tefsir de bulunmaktadır. Müellif, eserinin mukaddimesinde tefsir metodolojisi hakkında bilgi vermektedir. Kâşânî, te'vîl kabul etmeyen veya buna intiyaç hissedilmeyen ayetleri te'vîl etmek için uğraşmadığını,125 zâhir ahkâmdan te'vîl kabul etmeyenleri zâhir üzeretefsir etme gayreti güttüğünü, bu ayetlerden çok azını te'vîl ettiğini söyler.126 Te'villerinin kesinlik ifade etmediğini belirtmek için her surenin sonunda والله تعالى أعلم ifadesini kullanır. Bu yönüyle Te'vîlât, işarî ve zahiri tefsiri barındıran bir eser olma özelliğine sahiptir. Ayrıca, ağırlıklı olarak dirayet metoduyla yazılan eserde yer yer rivayetlere de yer verilmiş, Hz. Ali ve Câfer-i Sâdık'tan çok miktarda rivayette bulunulması, Kâşânî'nin Batınîolduğu düşüncesine sebep olmuştur.

\subsubsection{Rivayet Tefsiri Açısından Te'vîlâtü'I-Kur'an}

Te'vîlât'ta rivayet tefsirine de yer verilmektedir. Kâşânî, ayetlerin tefsirinden sonra sıkça mutasavvıflardan sözler ve az da olsa tasavvufî hikâyeler nakleder.

\footnotetext{
120 Bk. Zehebî, et-Tefsir ve'I-Müfessirûn, II/401; Ateş, işarî Tefsîr Okulu, ss.204-205.

121 Ateş, işarî Tefsîr Okulu, s. 244.

122 Alusî,Ebû Fadl Şihâbüddîn Seyyid Mahmûd, Rûhu'l Me ânî ve Tefsiri'l'-Kur'âni'l-Azîm ve Seb 'ilMesânî, Beyrut, ts., XXV/8.

123 Alusî, Rûhu'I-Meânî, XV/326.

124 Kâșânî, Hakâiku't-Te'vîl fî Dekâiki't-Tenzîl, vr. 1'; Kâșânî, Te'vîlât, I/5-9.

125 Kâşânî, Te'vîlât, I/9.

126 Kâşânî, Te'vîlât, I/10.
} 
Bazen de zahirî ve sufi tefsirlerden eser ismi vermeden "bazı tefsirlerde denildi ki, tefsirlerde zikredilir ki, bazı zahir ehli müfessir demiştir ki..." şeklinde nakillerde bulunur. Bir-iki yerde ayetin sebeb-i nüzûlü hakkında bilgi verir.127Bir-iki istisna dışında128 bu rivayetlerin sıhhati noktasında herhangi bir değerlendirmede bulunmaz. Te'vîlât'ta yer yer isrâiliyyâta yer verildiği görülmektedir. 129

Te'vîlât'ta kaynaklar genellikle "denildi ki, rivayet edildi ki..." tarzında müphem ifadelerle verildiğinden herhangi bir tefsir ya da müfessir ismi zikredilmez. Kendisinden nakilde bulunulan tefsirlerden de "denildi ki,130 rivayete göre,131 hukemâdan bazıları demişlerdir ki132, müfessirler dediler ki133, bazı tefsirlere göre,...."134şeklinde mübhem ifadelerle rivayette bulunulur. Te'vîlât'tın rivayet kaynaklarını, sahabeden Ömer (ö. 23/644)135, İbn Mesud (33/623)136, Ali (ö. 40/661)137, Aişe (ö. 59/678)138, İbn Abbas (ö. 68/687)139, Abdullah b. Ömer $(73 / 692)^{140}$ ve Câbir b. Abdillah (ö. 78/697)141; tâbiundan Saîd b. Cübeyr (ö. 95/713)142, Dahhâk b. Müzahim (105/723)143, Katâde b. Diâme (ö. 117/735)144, Câfer-i Sâdık (ö. 148/765)145, ve sufilerden Ebû Yezîd-i Bestâmî (ö. 234/850)146, Hâtim b. el-Esam (ö. 237/852)147 Cüneyd-i Bağdâdî (ö. 298/911)148, Hallâc-ı Mansûr, (ö. 306/919)149, Semnûn b. Hamza (ö. 320/932)150ve Ebubekr b. Şiblî (ö. 334/945)'den151 oluşturmaktadır.

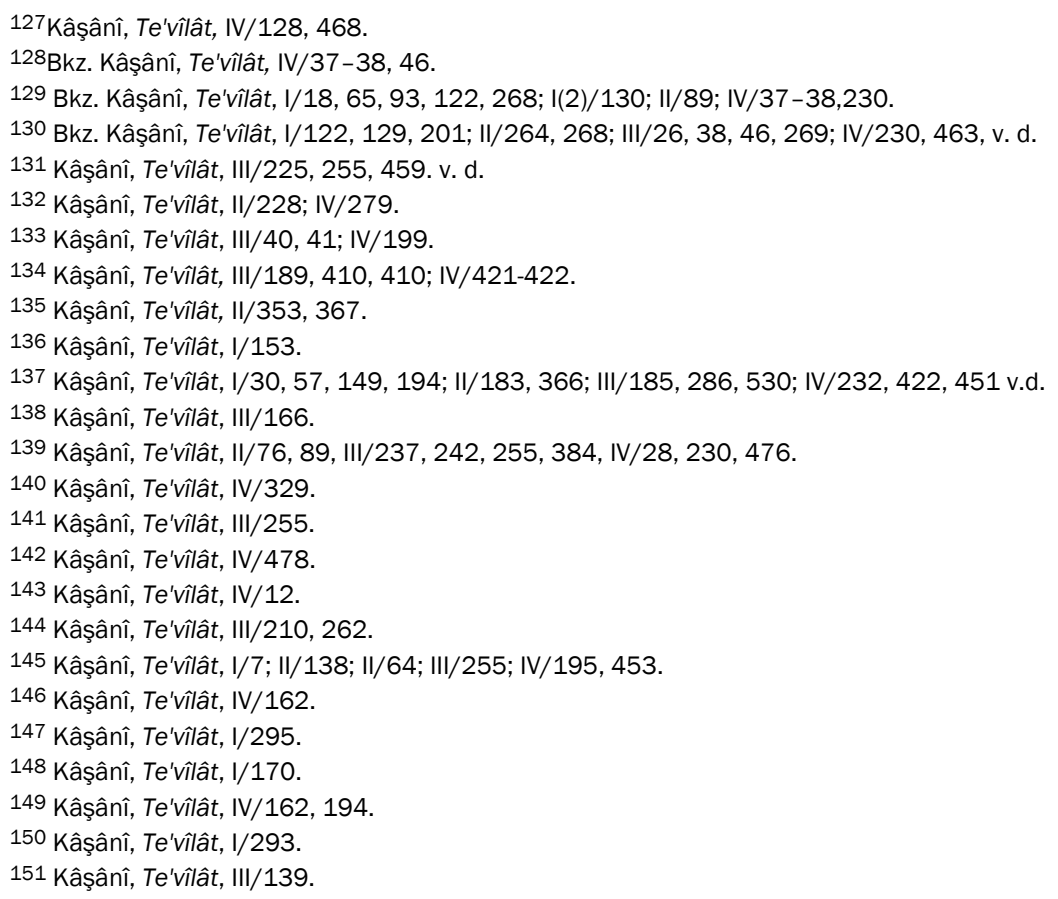




\subsection{Dirayet Tefsiri Açısından Te'vîlâtü'l-Kur'an}

Eserde gerek işarî yöntemle, gerek rasyonel/zahirî yöntemle olsun, çokça dirayet metodu ile yapılmış yoruma rastlanır. Bazen de her iki metodu birleştirerek yaptığı yorumlar görülmektedir. Te'vîlât'ta bu konuda dikkat çeken bir diğer husus da ayetlerin yorumlarında antropomorfizm ve hurufiliğe yer verilmiş olmasıdır. Kâşânî, ayetleri yorumlarken yer yer ayet,152 hadis, ${ }^{153}$ Arap dili, şiirle,154 istişhad yöntemine başvurmaktadır. Kâşânî, hurufu mukattaayı Allah'ın bu harfleri ile başlayan isimleriyle yorumlamaya çalışmaktadır. ${ }^{155}$

\subsubsection{Te'vîlâtü'I-Kur'an'da Zahiri Tefsir}

Te'vîlât'ta işarî yorumun yanı sıra zahirî yoruma da yer verilmektedir. Müfessirin zahirîyorumları daha çok ahkâm ve dilbilimsel izahlarda kendini göstermektedir. Kâşânî, bazen ayetlerin zahirî ve işarî yorumunu bir arada verir. ${ }^{156}$ Müfessir, Te'vîlât'ta, zahirî yorumu tefsir, Batınî yorumu ise te'vîl olarak değerlendirmektedir. Bu durumda Kâşânî'nin, tefsirine Te'vîlât'l-Kur'ân ismini vermesinin arka planında yatan sebebin, bu eserdeki işarî yorumların fazlalığı olduğu ortaya çıkmaktadır. Kâşânî ayeti bazen kendisi zahire göre yorumlarken, bazen de müfessirlerin ayet hakkındaki yorumlarını "Zahirî tefsirlere, müfessirlere gelince" şeklinde nakleder. Konuyla ilgili birkaç örnek verelim.

Kâşânî Bakara suresi 30. Ayetteki ونحن نسبح بحمدك ونقدس لكcümlesinde belirtilen tesbih ve takdisi şöyle tefsir eder:

"Tesbih ile takdis arasında bir fark vardır. Tesbih, Allah'ı şirk, acz ve noksanlıktan tenzih etmek demektir. Takdîs ise Allah'ı bir mekâna bağlııktan, bir işten etkilenme (infiâl) ve bir işte kudretsizlikten tenzih etmek demektir."157

Kâşânî, Kur'an'daki şer 'î ayetleri yer yer işarî yöntemle tefsir ettiği gibi, konuyla ilgili zahiri yorumlara da yer vermektedir. Kâşânî, ibâdetlerin konuluş/vaz' gerekçesini insan aklının idrak edemeyeceğini, aklın bunu kavramasının mümkün olmadığını, yani ibadetlerin emri ilâhîye imtisal için yapılması gerektiğini158 ayrıca, bedenî ve malî ibadetlere imtisalin gerekliliğini159 belirterek, ibadetleri, ilgili ayetlerdeki zahiri manaya göre yorumlamaktadır.

\footnotetext{
152 Kâşânî, Te'vîlât, I/22-23, 42, 45, 194, 239, 330; I(2)/35, 113, 181-182; II/7, 147, 218, 305; III/22, 160, 177, 184, 269, 419; IV/121, 457, 478.

153 Kâşânî, Te'vîlât, I/50, 93, I/194, 213, 309; II/7, 136, 159, 369, 408; III/101, 170, 184, 198, 250, 328, 412; IV/7, 127, 174, 248, 340, 442, 444, 452 v. d.

154 Kâşânî, Te'vîlât, I/69, 85-86, 146, 174, 284; III/61, 250; IV/203, 449.

155 Kâşânî, Te'vîlât, II/89, 263, 310; III/54; 234, 429; IV/28 82, 119, 230.

156 Bkz. Kâşânî, Te'vîlât, I/16, 72-73, 132, 172, 187, 199, 255, 352; II/52, 117 -118; III/2; IV/123, 154, 439, 461, v.d.

157 Kâşânî, Te'vîlât, I/60.

158 Kâşânî, Te'vîlât, IV/355.

159 Kâşânî, Te'vîlât, I/469-470.
} 
Müfessir, Bakara 262. ayette belirtilen infakı zahiri anlama göre şöyle yorumlar:

"Allah, infakın başa kakma ve gönül incitmeyi beraberinde getirebileceği noktasında insanları uyarmıştır. Bununla birlikte infak üç özelliği sebebiyle de övülmüştür. Birincisi, Allah'ın emrine muvafık olması, ikincisi, infakta bulunan nefse nispetle o kişideki cimrilik huyunu yok etmesi,üçüncüsü ise hak sahibine (muhtaca) birçok faydası olması yönüyledir. O zaman kim infak etmezse Allah'ın emrine muhalefet etmiş olur." ${ }^{160}$

Kâşânî'nin kısasla ilgili yorumu ise şöyledir:

"Kısas, adalet kanunlarından bir kanundur. O, düşmanlığı yok etmek için farz kılınmıştır. Kısas, Allah'ın gölgelerinden bir gölgedir."161

Kâşânî̀nin zahiri yorumlarının çoğunu dilbilimsel açıklamalar oluşturmaktadır. Müfessir, ayetlerdeki kelimelerin anlamı, nahvi ve sarfını zahire göre tefsir eder. Müfessirin kelimenin anlamına ilişkin yapmış olduğu zahiri yorumlara şu örnekler verilebilir.

Müfessir, Bakara 9. ayetteki يخادعون الله والذين أمنوا “Onlar Allah’' ve Müminleri kandırmaya çalışıyorlar" ifadesindeki "Muhâda 'a" kelimesinin iyiliği gösterip kötülüğü gizlemek şeklinde yapılan hile162 ve 15. ayette ويمدهم في طغيانهم يعمهون"Onları azgınlıkları içinde bocalayıp dururlarken kendilerine mühlet verir” cümlesindeki ki عمنfiilinin anlamının, kalbin körlüğü ve insanların azgınlıkları,163 aynı surenin 35. ayetindeki ولا تقربا هذه الشجرة فتكونا من الظالمين "Bu ağaca yaklaşmayın! Yoksa zalimlerden olursunuz"ifadesinde değinilen zulmün, örfte bir şeyi konumunun dışında bir yere koymak, sözlükte ise hakkı ve (verilmesi) zorunlu olan payı eksiltmek anlamında olduğunu164 ve 255. ayetinde zikredilen "Kürsü"nün ise, sözlükte küçük taht anlamına geldiğini belirtir.165Kâşânî, Hicr suresi 26. ولقد خلقنا الإنسان من صلصال "Andolsun Biz insanı kuru bir çamurdan, şekillendirilmiş bir balçıktan

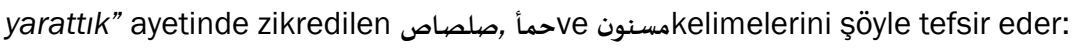

"Yani (bu ayetin manası biz insanı) iç içe geçmiş dört unsurdan (yarattık) demektir. O zaman حمأ başkalaşmış çamur, مسنون murat edilen şekli alabilmesi için üzerine su serpil(erek yumuşatılmış)miş çamur, صلصاصise, hava ile suyundan arındırılıp sıcaklık ile kurutulmuş çamur demektir."166Kâşânî, Kehf Suresi 29.

\footnotetext{
160 Kâşânî, Te'vîlât, I/205.

161 Kâşânî, Te'vîlât, I/156.

162 Kâşânî, Te'vîlât, I/34.

163 Kâşânî, Te'vîlât, I/39.

164 Kâşânî, Te'vîlât, I/65.

165 Kâşânî, Te'vîlât, I/192.

166 Kâşânî, Te'vîlât, III/95.
} 
ayette geçen المهلkelimesini şöyle tefsir eder: "İrin ve kir cinsinden olup Cehennem ehlinin vücudundan akan siyah akıntı” olarak tarif eder. ${ }^{167}$

Müfessir, yer yer ayetlerin sarfı, iştikakı ve kelimelerin buna göre aldığı anlamlar hakkında da bilgiler verir. Örneğin, Bakara suresi 36. ayetteki فأزلهما الشيطان عنها Derken, şeytan onların ayağını kaydırdı ve içinde bulundukları

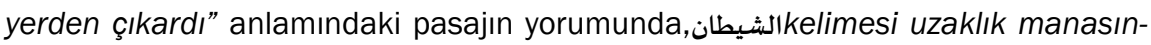
dadır. الشطونkelimesinden türemiş olup فَيَعَال vezninde gelmiştir. Onların şeytanları kovulmuş olup, uzaklıklarında batmış olanlar anlamındadır."168şeklinde bir yorum yapar. Yine, aynı surenin 248. ayetindekiإنَّ اية ملكه أن يأتيكم التابوت"Muhakkak, onun

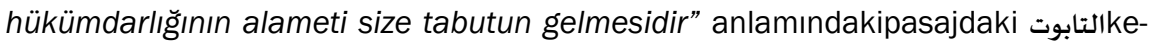
limesinin التوبkökünden türediğini ifade eder.169Son olarak, En âm suresi 59. ayetteki مفاتيح ifadesindekimesini sarf ilmine başvurarak şöyle tefsir eder:

eğer mahzen anlamında mîm'in fethi ile المفاتيح ların hepsini kaplayan hazîneler Allah'ın yanındadır" şeklindedir. Yok, eğer mîm'in

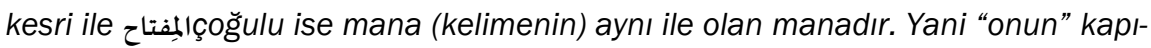
ları kapalıdır ve anahtarları Allah'ın elindedir" şeklindedir. ${ }^{170}$

Kâşânî, Te'vîlât'ta yer yer ayetlerin yorumunda kelimenin nahvine ve buna göre oluşan anlama da yer verir. Örneğin, Bakara 3 ila 5. الذين يؤمنون بالغيب ويقيمون أنزون

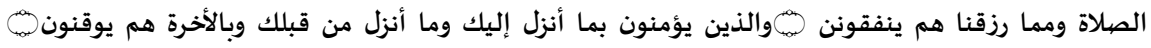
ayetlerini nahiv ilmine istinaden şöyle yorumlar:

الذين يؤمنون

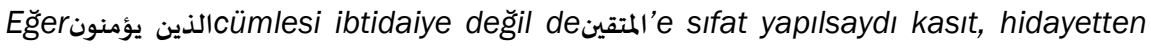
sonra takvada kemale ulaşanlar demek olurdu." 171

Kâşânî, Kehf suresi 2. Ayetteki قيماً لينذر بأسًا شديدًا من لدنه pasajında nahve dayalı olarak şöyle bir yorum yapar:

لينذرifadesi قيماًkelimesinin amiline müteallıktır. Bu durumda anlam "Allah

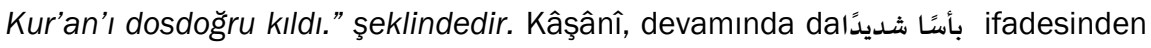
sonra birinci mefulün tamim amaçlı hazfedildiğini çünkü Mümin ya da kâfir olsun herkesin azapla karşılaşabileceği intimalinden hareketle Kur'an'ın tüm insanları azaba karşı uyarıcı olma vasfına dikkat çeker."172 Kâşânî, ayrıca Şûrâ suresi 23

\footnotetext{
167 Kâşânî, Te'vîlât, III/212.

168 Kâşânî, Te'vîlât, I/38.

169 Kâşânî, Te'vîlât, I/189.

170 Kâşânî, Te'vîlât, II/25.

171 Kâşânî, Te'vîlât, I/32.

172 Kâşânî, Te'vîlât, III/184-185.
} 


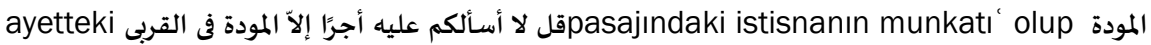
takdirinde mukadder bir (sıfata) müteallık olduğunu, bundan amaçlananın ise kati surette ecrin nefyi olduğunu belirtir."173

\subsubsection{Te'vilât'ta işârî Tefsir}

Kâşânî'nin Te'vîlât'ı aslı itibariyle işarî bir tefsirdir. Yer yer zahirî yorumlara rastlansa da yanında eserin büyük çoğunluğunu işarî yorumlar oluşturmaktadır. Kâşânî, eserinin mukaddimesinde de belirttiği gibi her ayeti işarî anlamda yorumlama gayreti içerisine girmemiş, te'vîl kabul etmeyen ayetleri ya zahir manada tefsir etmiş ya da ayetin tatbikini yapmıştır. ${ }^{174}$ Kâşânî, ayeti işarî metoda dayanarak yorumlayacağı zaman genellikle "Te'vîl", "Ayetin te'vîli şudur", "(Bu mana) câizdir", "Te'vîle gelince”, "Ayetin bâtın (yorumu)'na gelince..." gibi ifadeleri kullanır. Kâşânî özellikle ibadetler ve uhrevî hayat ile ilgili konuları işarî metodla yorumlar. ${ }^{175}$ Konuyla ilgili şu örnekleri verebiliriz:

Kâşâniإذذ فرقنا بكم البحر فانجيناكم وأغرقنا آل فرعون وأنتم تنظرون"Hani sizin için denizi yarmış, sizi kurtarmış, gözlerinizin önünde Firavun ailesini suda boğmuştuk" anlamındaki Bakara Suresi 50. ayette zikredile İsrailoğulları hakkında şöyle bir yorum yapar:

"(Ayette zikredilen) İsrâiloğullarını ilk önce ruhani kuvveler ve onlara verilen nimetler olarak tevil etmek mümkündür."176şeklindeki yorumuyla, İsrailoğullarını, zahiri anlamıyla değil, işari olarak te'vil etmektedir.

و إذ استسقى موسى لقومه فقلنا اضرب بعصاك الحجر Müfessir, Bakara Suresi 60. ayetteki فانفجرت منه اثنتا عشرةعينًا قد علم كل أناس مشربهم"Hani, Musa kavmi için su istemişti. "Biz de asanı vur." Demiştik. Böylece kayadan on iki pınar fışkırmış, her boy kendi su alacağı yeri bilmişti." pasajında şöyle işarî bir yorum yapar:

"Yani onlar ruh semasından hikmet ve mazâhırın inmesini istediler. Ardından oradan ilim suları fışkırdı. Ardından herkes ilmi içeceği yeri bildi. İkinci tevile gelince o da şudur: Biz kalp Musa'sına nefis asasını dimağ taşına vurmayı emrettik. Oradan her birine tahsis edilmiş on iki kuvve gözü fışkırdı."177

Kâşânî, Bakara Suresi 189. ayetteki اليسألونك عن الأهلة قل هى موا قيت للناس والحج وليس "Sana hilallerden soruyorlar. De ki! Onlar insanlar ve hac için vakit ölçüleridir. İyilik evlere arkalarından girmeniz değildir." mealindeki pasajda zikredilen hilaller ve hac hakkında şöyle bir işarî yorumu yapar:

"Yani (hilaller) Allah yolunda amel etme, sülûk, kalp evini tavaf ve marifet ma-

\footnotetext{
173 Kâşânî, Te'vîlât, IV/27; diğer örnekler için bk. Kâşânî,Te'vîlât, I/254; IV/450.

174 Kâşânî, Te'vîlât, I/(2), 275; II/197, 357-358; III/275; IV/474.

175 Kâşânî, Te'vîlât, I/323; III/30, 68; IV/170, 450, 452.

176 Kâşânî, Te'vîlât, l/74-75.

177 Kâşânî, Te'vîlât, l/81-83.
} 
kamında durma zamanıdır. (İilik) de kalp evlerine beden hislerinden alınmış (mülhem olmayan) bilgi ve hisleriniz yoluyla girmeniz değildir."178 Kâşânînnin bu ayette hac ibadetini işarî olarak yorumladığını görmekteyiz.

Kâşânî, uhrevi meseleleri de işari metotla yorumlamaktadır. Örneğin, sıfât, zât, ef âl,179 kalp180 ve nefs'181 olmak üzere beşe ayırdığı cennette verilecek nehirler ve eşleri şöyle yorumlar:

"(Cennetteki nehirler) kalp ilimlerinden tecelliyât ilimlerinin nehirleridir. Burada eşler(den kastedilen) ise, bedenî surette pak ilâhî sıfatların mazharları olan önceki ruhlardır."182

Müfessir Araf suresi 18. ayette ise cehennem hakkında da şöyle bir işarî yorum yapar:

“Cehennem vücut mertebelerinin en aşağısıdır. Cehennemlikler orada ebedi nimet lezzetleri, beka zevkleri ve ruhi ve hakkani kemâlattan mahrum kalacaktır. Onlara, asıl hedef olan Allah'(ın rızası)tan uzak olma (hırman) ateşi ile azap edilecektir. 183

Kâşânî, kıssalarda anlatılan bazı gerçeklikleri de işarî olarak yorumlar örneğin,Mâide suresinde belirtilen gökten inen sofrayı şöyle yorumlar:

"(Burada sofra) Ruh âleminden inip, çeşitli ilim, hikmet, maarif ve hükümleri içeren, içinde kalbin gıdası ve ruhun gıdası hayatı ve zevki bulunan şeriat demektir."184Aynı şekilde Tâhâ Suresi 12. ayette Hz. Musa'ya Tur dağında yapılan فاخلع نعليكemrini ise işarî olarak şöyle yorumlar:

"Yâni ruhun ve bedeninle iki dünyadan vazgeç (demektir.) Çünkü (insan) bu ikisinden vazgeçince iki cihandan da vazgeçer."185

İbn Arabî (ö. 638/1240)'nin en önemli takipçisi kabul edilen Kâşânî186 yer yer ayetlerdeki işarî yorumlarında O'nun sistemleştirdiği vahdeti vücut düşüncesine uygun yorumlar da yapmaktadır. Örneğin müfessir, Bakara suresi 115. ayetteki pasajında yapmış olduğu yorum bu kapsama dâhil olmaktadır.

"Yani (mana) Allah'ın bütün sıfatlarıyla tecelli etmiş Zatını (görürsünüz demek-

\footnotetext{
178 Kâşânî, Te'vîlât, I/161-162; Kâbe hakkındaki benzer yorumlar için bk. Kâşânî, Te'vîlât, I/120-121; 164-165.

179 Kâşânî, Te'vîlât, I(2)/108; IV/240.

180 Kâşânî, Te'vîlât, II/372.

181 Kâşânî, Te'vîlât, IV/459.

182 Kâşânî, Te'vîlât, I(2)/21; benzer yorumlar için bk.Kâşânî, Te'vîlât, I/51-52; II/221; III/233; IV/452, v.d.

183 Kâşânî, Te'vîlât, III/96; benzer yorumlar için bk. Kâşânî, Te'vîlât, I/49-51, 319; II/62, 406-407; III/ 76; 146-147; IV/236, 453 v.d.

184 Kâşânî, Te'vîlât, I(2)/202.

185 Kâşânî, Te'vîlât, III/268; benzer yorumlar için bk. Kâşânî, Te'vîlât, I/25, 49, 64, 109, 121, 161, 249, 323; II/295, 400; III/20, 55, 145, 230; IV/5, 25, 66, 136, 202, 282 374, 450, 460, 469, v.d.

186 Uludağ, "Işârî Tefsir", s. 427.
} 
tir). Ya da Allah'ın kalplerinize doğması ve sizin şuhûd ve fena halinizde cemal sıfatı ile kalbinize tecellisi ve yine Zatının bütün sureti, gizliliği ve celâli ile sizin fenadan sonra beka halinizde kalplerinizde batması daAllah'a aittir. Yöneldiğiniz her cihette o vakit Allah'ınveçhi vardır. Hiçbir şey yoktur. Sadece onun kendisi vardır."187

Müfessir, başka bir yerde de şu yorumu yapar:

"Varlık âleminde Allah'tan başka ilâh yoktur. Onun dışında kendisine ibadet edilene yapılan ibadetler de sadece Ona aittir. ...Çünkü Ondan başka mabut yoktur. Ondan başka mevcut (varlık) da yoktur. ${ }^{188} \mathrm{Bu}$ ifadelerin son cümlesinde vahdeti vücut anlayışı ifade edilmiştir.

Müfessirin şu yorumunda da vahdeti vücut anlayışının etkisi açık bir şekilde görülmektedir

"Yani O, nuru ile sana zuhur eder ve yaratması ile vücudunun ufkundan doğar. Mağribde senin vücudunda gizlenip nuru sende batan ve gizlenendir. Ondan başka varlıkta ilâh yoktur. Yani varlıkta Ondan başka ibadet edilecek yoktur. O Evvel'dir, Âhir'dir, Zâhir'dir, Bâtın'dır."189

\subsection{Te'vîlât'ta Her İki Yöntem Kullanılarak Yapılan Tefsir}

Daha önce de ifade ettiğimiz gibi Kâşânî, Te'vîlât'ta işarî ve zahiri tefsir yöntemini uygulamaktadır. Kanaatimizce Kâşânî̀nin, Zahirîler ile Batınîleriaynı anda eleştirmesinin 190 sebebi de tefsirde uyguladığı bu yöntemdir. Müfessir bu yöntemi bazen ayrı ayrı uygularken, bazen de aynı ayet üzerinde uygulayabilmektedir. Müfessir her iki yöntemi birlikte uygulayacağı zaman genellikle önce ayetin zahirî yorumunu ardından işarî yorumunu yapar.

Kâşânî,Araf suresi 141. ayetteki وإذ أنجيناكم من ال فرعون "Hani Biz sizi Firavun ailesi (nin zülmü)'nden kurtarmıştık" pasajını şöyle yorumlar:

“Ayetin zahiri ve tefsiri, (İsrâiloğullarına verilen) nimetin hatırlatılmasından anIaşıldığına göre muhabbetin artması içindir. Bâtını ve teviline gelince o da, vücut mülkü ve kul edinilmiş beden şehrinde kullanılan gururu sebebiyle haktan uzaklaşan nefsi emmaredir. Nefsi emmare ile, onun vehm, hayal etme ve ettirme, öfke, şehvetten müteşekkil kuvveleridir. "191

Kâşânî, Enâm suresi 125. ayete şöyle bir yorum yapar:

Müfessir, ولقد خلقنا السموات والأرض وما بينهما فى ستة أيام وما مسنا من لغوب"Andolsun, gök-

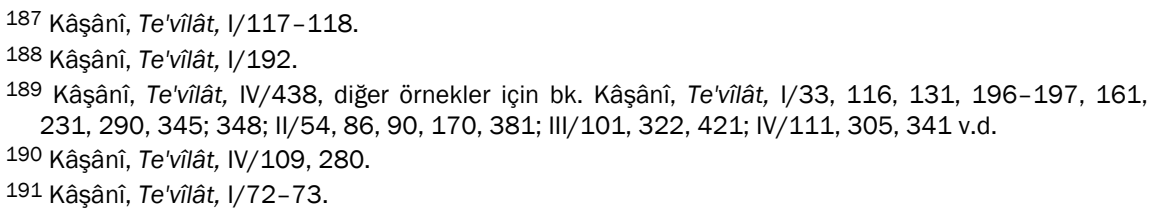


leri, yeri ve ikisi arasındakileri altı günde yarattık. Bize yorgunluk da dokunmadı." MealindekiKâf suresi 38. ayetini şöyle yorumlar:

"Eğer gökleri ve yeri zahire göre tefsir edersek yedi cihet anlamındadır. Gökleri ruhlar ve yeri de cisim olarak tevil edersek, o da mahlûkatı kuşatan altı araz topIuluğunun bir araya gelmesiyle oluşan cevher, görecelik, keyfiyet ve kemiyet varlıklarının toplamından ibaret olan âlemlerindeki ceberut ve melekût ve mülk âlemlerindeki altı varlığın (mümkinatın) suretleridir."192

Müfessir bazen sadece ayetin zahiri manasını kabulle yetinerek yorum yapmaz ve işarî çıkarımda bulunur. Örneğin, نحن نقص عليك أحسن القصص بما أوحينا إليك هذا 'Biz sana bu Kur’an’ı vahyederek en güzel kıssayı anlatacağız. Oysaki sen bundan önce(kıssadan) habersizdin." mealindeki Yusuf suresinin 2. ayetinde şöyle bir yorum yapar:

"Bu surenin lafzı ve terkibindeki i'câzı ve zahir manasını ve vakıaya mutabık olduğunu kabul etmekle birlikte batını da sülük ve sâlikin durumuna çok iyi bir şekilde delalet etmektedir."193

Kâşânî, Mutaffifîn suresinde de şöyle bir yorum yapar:

“(Ayetin anlamı) ölçü ve tartıda insanların haklarını yiyenlere (yazıklar olsun! şeklindedir.) Adalet ve tartılan şeyleri (ifade eden) gerçek tartıyı zahiren yorumladıktan sonra, mutaffifin, kendi kemalatını insanlar üzerinde üstünlük vesilesi addeden insanlar şeklinde yorumlamak mümkündür. Onlar, ilmî ve amelî faziletlerini insanlara göstererek daha fazla hayranlık uyandırmak ve gururlanmak isterler. Kendi kemâlâtları ile başkalarınınkini karşılaştırdıklarında ise, onları düşük hakir gösterirler. Her iki durumda da adalete riayet etmezler."194

\subsection{Te'vîlât'ta Antropomorfist Yorumlar}

Sözlükte insanbiçimcilik olarak tanımlanan195, gerçekte psikoloji alanıyla ilgili olan yorum biçimi olup Kur'an sembolizminin mikro kozmik düzeye uygulanması196ve Kur'an kıssalarını ruha ve ruh kuvvetleri arasındaki manevi bağa uygulamak şeklinde tarif edilen antropomorfizme Te'vîlât'ta sıkça rastlanmaktadır. ${ }^{197} \mathrm{Bu}$ yöntemi de te'vilinin mümkün olmadığını belirttiği ayetlerde uygular.198 Kâşânî, genel olarak ayeti zahire göre tefsir ettikten sonra "Tatbîk, tatbîke gelince, tatbîki istenirse..." gibi lafızlarla antropomorfist görüşlere de yer verir. Kâşânî, Kur'an'da

\footnotetext{
192 Kâşânî, Te'vîlât, IV/232-233; benzer bir yorum için bk. Kâşânî, Te'vîlât, I/378.

193 Kâşânî, Te'vîlât, III/2; benzer bir yorum için bk. Kâşânî, Te'vîlât, III/54.

194 Kâşânî, Te'vîlât, IV/457.

195 Komisyon, Türkçe Sözlük, TDK. Basım Evi, Ankara, 1988,I/118.

196 Lory, Kâşânî'ye Göre Kur'an'ın Tasavvufi Tefsiri, s. 34; Konu hakkında ayrıntılı bilgi için bk. Ateş, işârî Tefsir Okulu,ss.309-320.

197 Ateş, işârî Tefsir Okulu, s. 309.

198 Kâşânî, Te'vîlât, III/275; IV/474.
} 
zikredilen peygamberleri ve bazı şahısları da tatbik eder. Müfessir, zaman zaman da tatbiki okuyucuya bırakır. 199

Kâşânî̀ye göre hemen her varlık bir durum ya da duyguyu temsil eder. Buna göre örneğin, Hz. Âdem âlemin kalbi olan küllî nefsi natıkayı,200 Musa201, Zülkarneyn ${ }^{202}$, Yunus, ${ }^{203}$ Meryem ${ }^{204}$ ve Harun ise aklı205, Cebrail206 ve Yahya (a.s.) ise faal aklı207 temsil etmektedir.

Örneğin müfessir, Bakara suresi 44. تأمرون الناس بالبر وتنسون أنفسهم و أنتم تتلون تأكترون Kiz Kitabı okuyup durduğunuz halde kendinizi unutup başkalarını iyiliği mi emrediyorsunuz?" ayetinde zikredilen Kitab/Tevrat'ın antropomorfist yorumunu şöyle yapar:

"Siz akıl meleği vasıtasıly kalp nebisine Ruh(un) Rabbi tarafından indirilmiş olan ma 'kûlât kitabını okumaktasınız. Akledemiyor musunuz?"208

Müfessir, Meryem suresi 3. ayetteki إذ ناى ربه نداء خفيًا "Rabbine gizlice nida etti." ayetinde zikredilen "nidayı" şöyle tatbîk eder:

"Bil ki, "nidâ etti" sözünün tatbiki Ruh Zekeriya’sı heyulanî aklın istidat makamında gizlice (nidâ etti.) demektir."209Müfessir, bu ifadesiyle, Hz. Zekeriyya (a.s.)yı bir hayal ürünü olarak kabul eder ve dolayısıyla onun seslenmesini ise insana verilen kabiliyet olarak yorumlar.

Kâşânî, Yusuf suresi إذ قالوا ليوسف و أخوه أحب إلى أبينا منا و نحن عصبة 8. ayette uzunca bu tarz yoruma başvurur. Buna göre Hz. Yusuf (a.s.) kalbi,210 üvey kardeşleri aklî kuvveleri, öz kardeşi ise kalbi temsil etmektedir. ${ }^{211}$ Kurda atılan iftira kuvve-i ğadabiyeyi, kurdun yemesi ise kuvve-i şeheviyyeyi ve hisleri,212 Yakubun gözünün kör olması akıl nurunun kaybolmasını Yusuf'u kuyudan çıkaran kervan ise fikrî kuvveyi213 Yusuf'un güç sahibi kılındığı Mısır nefsi levvâmeyi214 temsil eder.

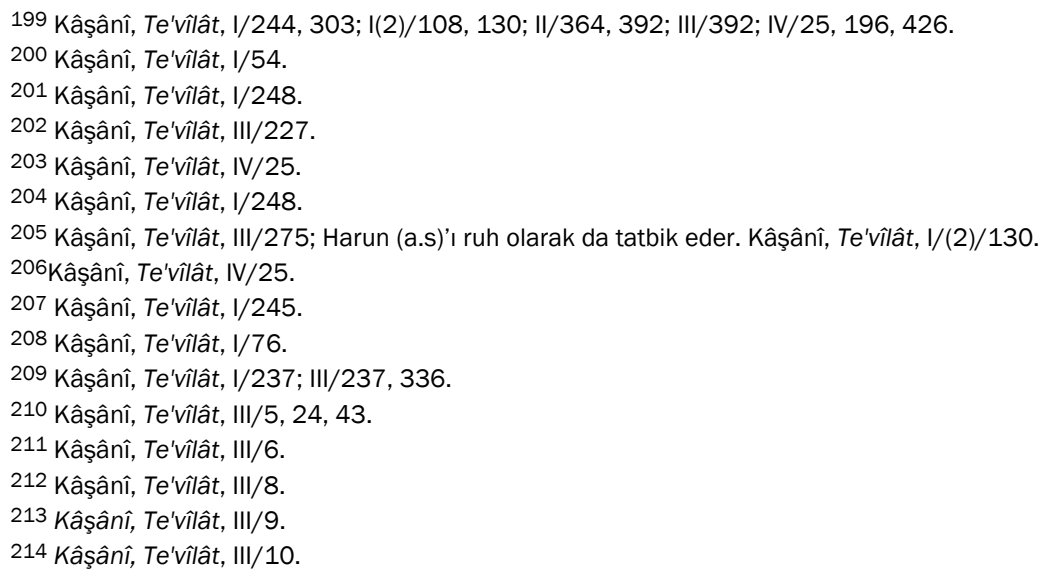


Ayrıca Züleyha'nın Hz. Yusuf'a olan aşkı ruh nurunun parlamasını 215 yedi inek ve başak ise akıl ve fikir kuvvelerine 216 işaret etmektedir.

Müfessir Fil suresinin tefsirinde de aynı yöntemi izler ve şöyle der:

"Bu sure klyamet ahvali ve buna benzer ayetlerde olduğu gibi tevil kabul etmez. Tatbike gelince, Habeşî nefis Ebrehe, hakikatte Allah'ın evi olan kalp Kâbe'sini yıkmaya ve onu istila etmeyi ruhani kuvâ hacılarını bina ettiği cismânî tabiat kilisesine döndürmeyi ve onu yüceltmeyi isteyince gurura kapılmıştır."217

\subsection{Te'vîlât'ta Hurufi Yorumlar}

Harf ve kelimelerin gizli anlamlar taşıdığı fikrinden hareketle ayet ve hadisleri, harflere ve sayılara verilen yeni anlamlarla izah etmek şeklinde tarif edilen hurufiliğe218 Te'vîlât'ta sadece birkaç yerde rastlanmaktadır. Cifr ilminin kaderde vuku bulacak şeylerin levhası olduğunu söyleyen Kâşânî'nin²19 besmelenin tefsirinde yaptığı konuyla ilgili değerlendirmeleri şöyledir:

"Peygamberler (a.s.) hecâ harflerini mevcudat mertebesine koymuşlardır. Îsa (a.s.), Emîru'l-Mü'minîn Ali (r.a.) ve bazı ashabın kelamında buna işaret eden şeyler bulunmuştur. Bu sebeple mevcûdât "Bismillâh'ın Bâ'sından doğmuştur" denilmiştir. Çünkü o, Allah'ın zatının önüne konulmuş harfi takip eden harftir. O, Allah'ın "Ben, bana senden sevimli ve değerli bir şey yaratmadım. Ben seninle veririm, seninle alırım, seninle mükâfatlandırır ve sözü seninle sonlandırıım dediği akl-ı evvele işarettir.

Söylerken besmelenin harfleri 18, yazıldığında ise 19'dur. Kelimeler ayrı yazıldığında harfler de 22'ye ayrılır. 18, kendisiyle ifade edilen on sekiz bin âleme işarettir.

Elif, sayı mertebelerinin geri kalanını şamil tam bir sayıdır. 0 , kendisinin üstünde bir sayı olmayan mertebelerin temelidir. Âlem-i ceberut, âlem-i melekût, arş ve kürsî, yedi gök, anasırı erbaa, her biri kendi cüzüne ayrılan üç mevâlid olan âlemlerin asılları olarak isimlendirilmişlerdir. 19 sayısı ki, onda insanî âlemle birlikte bir de işaret vardır. Eğer o, hayvan âlemine dâhilse, ancak şerefi itibariyle ve her şeyi içine alması ve diğer bir âlemin varlığını kapsaması sebebiyledir.

Gizli üç elif ki o, kopukluk durumunda yirmi iki harfin tamamlayıcısıdır. O da zat, sıfat ve ef âli itibariyle gerçek ilahîâleme işarettir. O da tahkik ehline göre üç

\footnotetext{
215 Kâşânî, Te'vîlât, III/14.

216 Kâşânî, Te'vîlât, III/27.

217 Kâşânî, Te'vîlât, IV/474, diğer örnekler için bkz. Kâşânî, Te'vîlât, I/77, 120, 163, 244, 253; I(2)/82, 100,108, 130, 131; II/364, 392; III/5, 19, 24, 43, 227, 237, 297, 336, 354, 526; IV/25, 200, 426, v.d.

218 Bk. Ünver, Mustafa, Hurufilik ve Kuran, Nesimî Örneği, Fecr Yay. 1. Baskı, Ankara, 2003, s. 11; Aksu, Hüsamettin, "Hurûfilik", DiA, İstanbul, 1998, XIIX/408.

219 Kâşânî, Te'vîlât, I/25.
} 
âlemdir. Onda bu âlemlerin en yüce insani mazhar ve ilâhî âlemin ihticâbının zuhûruna işaret vardır. Hz. Peygamber'e Besmele'deki bânın elifinin nereye gittiği soruldu. O da "Onu şeytan çaldı ve Bismillâh'ın bâsının elife ivaz olarak uzatılmasını istedi" demiştir. Bunda yayılan rahmet suretinde ilahî zayıflık ihticâbına ve onun ancak ehli tarafından bilinmesi açısından zuhuruna işaret vardır." 220

Kâşânî'nin hurufi mahiyetteki yorumları kendisini daha çok huruf-u mukataaların yorumunda hissettirmektedir. Kâşânî, Bakara Suresinin ilk ayetindeki huruf-u mukataayı şöyle yorumlar:

(Allah) bu üç hafle (الم) kül olması yönünden varlığın hepsine işaret etmektedir. Elif, vücudun ilki olan Zat'a, lam, Cibrîl olarak isimlendirilen faal akla ve o kaynaktan fişkıran ve sona doğru akan varlığın ortasına işarettir. Mîm, varlığın sonu olan Hz. Muhammed (a.s.) işarettir. 221

Müfessir, bu harfleri Allah ve peygamberlerin isimleri ile bağlantılı bir şekilde de yorumlar. Bununla birlikte aynı harf için farklı yerlerde çoğunlukla aynı manayı verse de yer yer farklı anlamlar verdiği de görülmektedir. Kâşânî'nin, huruf-u mukattaa için yapmış olduğu bu tarz diğer yorumlar şöyle özetlenebilir:

Hâ, (Allah'ın)Hak,222 tâ, Tahir, sîn, Selâm, mîm, Muhît ismine223 ya da Hz. Muhammed'in manasına, 224 râ, Muhammedî surette tecelli eden rahmete,225 Kâf, (Allah'ın) Kâfî, hâ, Hâdî, yâ, Vâkî, a yn, âlim, sâd, Sâdık ismine,226 kâf, Hz. Peygamberin kalbi ya da dağa,227 lâm, külli akıl Cebrail'e228 ya da zatı ilahiye229 nûn külî nefse 230 ve Yâsîn, insana231 işaret etmektedir.

\section{SONUÇ}

Doğum yeri ve tarihi kesin olarak bilinmeyen Abdürrezzâk Kâşânî, h. VII/m. XIII. asrın ikinci yarısı ile h. VIII/m. XIV. asrın ilk yarısında Iran'ın Irak-ı Acem deni-

\footnotetext{
220 Kâşânî, Te'vîlât, I/17-18; Kâşânî'nin yer yer Te'vîlât'ta isrâiliyyâta yer verdiğini ve rivayetlerin sıhhatine dikkat etmediğini belirtmiştik. Müfessirin, besmeleyi yorumlarken kullanmış olduğu bu rivayet de bu açıdan sorunludur. Zira tamamen dilbilimsel bir gerekçeye binaen yapılan bu hazfin, Arap dilbilimi açısından değil de İslam'ın temel prensiplerine aykırı bir rivayetle izah edilmeye çalışııması Te'vîlât'taki bazı rivayetlere intiyatı yaklaşılmasını gerekli kılmaktadır.

221 Kâşânî, Te'vîlât, I/23.

222 Kâşânî, Te'vîlât, IV/82, 114.

223 Kâşânî, Te'vîlât, III/429.

224 Kâşânî, Te'vîlât, II/89.

225 Kâşânî, Te'vîlât, II/310.

226 Kâşânî, Te'vîlât, III/237; Kâşânî, Sâd'ın Muhammedî surete işaret ettiğini de belirtir. Kâşânî, Te'vîlât, II/89.

227 Kâşânî, Te'vîlât, VI/230.

228 Kâşânî, Te'vîlât, I/23.

229 Kâșânî, Te'vîlât, II/89.

230 Kâşânî, Te'vîlât, vl/398.

231 Kâşânî, Te'vîlât, IV/2.
} 
len "Cibâl" taşrasında yaşamıştır. Doğum tarihi hakkında bilgi bulunmayan müfessirin vefat tarihinde de kesinlik bulunmamakla birlikte çoğunluk 730/1330 tarihinin doğruluğunu kabul etmiştir.

Kâşânî, yaşadığı dönemde İlhanlı Devleti'nin hâkim olduğu İran'da yöneticilere de yakın olmuştur. Dönemin Moğol hükümdarı Olcaytu Han (ö. 715/1316), Said Bahadır Han (ö. 735/1335) ve vezir Reşîdüddîn Fazlullah b. Ebi'l-Hayr (ö.717/1318) ve Hoca Gıyâseddin Muhammed ile yakın ilişkilerde bulunmuş, onlarla seferlere katılmış ve bazı eserlerini devrin yöneticilerine ithaf etmiştir.

Velûd bir müfessir olan Kâşânî, ilmî faaliyetlerini ömrünün çoğunluğunu geçirdiği Tebriz'de sürdürmüş, çoğunluğu tasavvuf sahasına ait olan otuz beş eserini burada kaleme almıştır. Eserlerinden iyi bir eğitim aldığı anlaşılan Kâşânî, ilk eğitimini, kendisinin yetişmesinde önemli bir yeri bulunan hocası Natanzî (ö. 699/1300)'den almış, daha sonra Natanzî'nin yönlendirmesi ile Kîşî (ö. 694/1295)'den zâhir ve bâtın ilimlerini almıştır. Kâşânînin hocaları hakkında olduğu gibi talebeleri hakkında elimizde yeterli bilgi yoktur. Bununla birlikte Kâşânî'nin birçok talebe yetiştirdiği tahmin edilmektedir. Osmanlı Devleti'nin ilk müderrisi Dâvûd-u Kayserî'ye hocalık yaptığı bilinmektedir.

Müellif, büyük oranda Fusûsu'l-Hikem adlı eserini şerh ettiği İbn Arabî'nin ve onun yaymış olduğu vahdeti vücut anlayışının etkisi altındadır. Eserlerinde bu anlayışın etkisinde olduğu açık bir şekilde hissedilmektedir. Bu sebeple sufi olmasına rağmen, Bâtıni olmakla bile itham edilmiştir. Bununla birlikte Kâşânî'nin hayatına, hocalarına, yazmış olduğu eserlere bakıldığında onun sufi olduğu kolaylıkla anlaşılmaktadır. Bununla birlikte eserlerinde Batıniliği çağrıştıracak herhangi bir ifade olmadığı gibi, Te'vîlât'ta Batınileri yer yer eleştirdiği ifadelere rastlanmaktadir.

Kâşânî'nin Te'vîlât'ı defalarca Tefsîr-i Şeyhi'l-Ekber adıyla ibn Arabî'ye nispetle basılmıştır. Bunun nedeni, eserde sıkça İbn Arabî'nin savunmuş olduğu vahdeti vücut düşüncesine yer vermesi sebebiyle üslubunun İbn Arabî'ye benzemesi ve ticari kaygılar olarak belirtilmektedir. Ama yapılan araştırmalar ve Kâşânî'nin Te'villât'ta ve diğer eserlerinde verdiği bilgiler, eserin İbn Arabî'ye değil, Kâşânî'ye ait olduğunu net bir şekilde göstermektedir. Bu eser, müellifin yazmış olduğu Hakâiku't-Te'vîl fi Dekâiki't-Tenzil adlı tefsirinin te'vîl bölümünden oluşan muhtasarıdır.

Kâşânî kendisinden sonra başta Davud-u Kayserî, İsmail Hakkı Bursevî, Âlûsî, olmak üzere birçok müfessiri etkilemiş, yüzden fazla alıntı yapılan Bursevî'nin Rûhu'l-Beyân tefsirinin temel kaynakları arasında gösterilmiştir. Bu da Kâşânî'nin işarî tefsirdeki önemini göstermek açısından yeterlidir.

Te'vîlât, ayetlerin Mushaf tertibine göre tefsir edildiği ve dirayet metodunun esas alındığı özlü bir tefsirdir. Tüm ayetlerin tefsir edilmediği eserde ayetler ağırıkIı olarak işâri metotla yorumlanmış, zahiri tefsire de yer verilmiştir. Kâşânî, zahir 
tefsir için tefsir, işarî tefsir için ise tevil ve bâtın ifadelerini kullanmıştır. Ayrıca, ayetler ağırlıklı olarak vahdeti vücutdüşüncesi ekseninde yorumlanmış, ye yer Hurufiliğe ve antropomorfizme yer verilmiştir. Kâşânî, ayetlerin yorumunda sıkça başka ayetlere ve hadislere, şiire ve Arap diline müracaat etmiştir. Yer yer rivayetlere de yer verilen eserde, bilgiler arasında sıhhat açısından değerlendirme yapılmadığı için israilî bilgilere de rastlanmaktadır. Eserde yer yer sufilerden rivayetlerde bulunulur ve tasavvufî hikâyeler nakledilir.

\section{Kaynaklar:}

» Afifi, A.E, Muhyiddîn ibnü'l-Arabî'nin Tasavvuf Felsefesi,(ter.Mehmet Dağ), Ankara Ü. İ.F. Yay. Ankara, ts.

" Âga Büzürgi Tahranî, ez-Zerîa ilâ Teşânîfi'ş-Şerîa, Beyrut, ts. (I-XXV).

" Alkış Abdürrahim, "Sermediyet ve Abdurrezzâk-ı Kāşânî̉nin Risâle fí Beyâni Mikdâri's-Seneti'sSermediyye ve Ta 'yîni Eyyâmi'l-Ilâhiyye İsimli Eseri”,Marmara Ü.I.F.D., 2009/1, sa. 36, ss. 207-235.

" Aydın, Mehmet, Din Felsefesi, izmir, 1992.

" Aydın, M. Akif, “imâmet”, DiA, İstanbul, 2000, 22/203-207.

" Bağdadî, İsmail Paşa, Hediyyetü'l-Ârifîn, Esmâü'l-Müellfîn ve Âsâru'l-Musannifîn, İstanbul, 1951, (I-II).

" Bayraktar, Mehmet, “Dâvûd-i Kayserî",DiA, İstanbul, 1994, IX/32-33.

» Bilmen, Ömer Nasuhi, Büyük Tefsir Tarihi, (Tabakâtü'I-Müfessirîn), Ankara, ts. (I-II).

» Brockelmann, Carl, Geschichte Der Arabischen Litteratur Ester Suplementend (GAL) Leiden, 1938.

" Cami, Abdurrahman, Nefehâtül' Üns min Hadarât'il Kuds çev.ve şerh Lâmiî Çelebi, b.y.y., ts.

Cezerî, İzzeddin Ebu'l-Hasen b. Esîr, el-Lübâb fî Tehzîbi'I-Ensâb, Beyrut, ts. (I-III).

" Davud el-Kayserî, Mahmûd b. Muhammed, Matla'u Husûsi'I-Kilem fí Ma'ânî Fusûsi'I-Hikem, Kral Suud Üniversitesi Ktp, nu: 2950z/189gm.

Demirli, Ekrem, "Vahdet-i Vücûd", DiA, Ankara, 2012, XXXXII/431-434

Duman M. Zeki-Altundağ Mustafa, “Hurûf-ı Mukattaa”, DiA, İstanbul, 1998, XVIII/401-408.

» Ergül Necmeddin, "Abdurrezzâk Kāşânî (ö. 730/1330)'nin Hayatı, ilıî̀-Tasavvufí Kişiliği ve Eserleri" Birey ve Toplum, Bahar, 2013, c. 3, sa. 5, ss. 93-125.

" Hamevî, Şehâbuddîn Ebû Abdillah Yâkût, Mucemu'I-Buldân, Beyrut, (I-V).

" Huart, Cl. "Kâşân"M.E.B.i.A. İstanbul, 1997, VI/404.

İbn Âșûr, Muhammed et-Tâhir, et-Tahrîr ve't-Tenvîr, Tunus, 1984,( I-XXX).

Karadaş, Cağfer, “Dâvûd-i Kayserî ve Genel Hatlarıyla Düşüncesi”,Uludağ Ü.I.F.D., 2006 c. 15, sa. 2, ss. 1-18.

" Kâşânî, Abdürrezzâk Ebü'l-Ğanâim, Hakâiku't-Te'vîl fî Dekâikı't-Tenzîl, Süleymaniye ktp. Fatih nr: 113.

" ___, Istılâhât-ı Sûfiyye, tahk. Abdülâl Şâhîn, Dâru'I-Menâr, 1992.

"—_ Letâifu'l-A'lâm fí Işârât-i Ehli'l-Illhâm, tahk. Ahmed Abdürrahim es-Sâyih-Âmir en-Neccâr, Kahire, 2005.

"__ Şerhu Fusûsi'l-Hikem, Matbaatu'I-Meymene, Mısır, 1321.

" ___ Tefsîri'ş-Şeyhi'I-Ekber (Te'vilâtü'I-Kur'âni'I-Hakîm), 1313, Hasan Halebî, (Hazin Tefiri kenarında) (I-IV).

» Katip Çelebi (Hacı Haliffe), Keşfüzzünûn an Esâmi'I-Kütüb ve'I-Fünûn, M.E.B. Yay., İstanbul, 1971, (I-II).

" Kaya, Mehmet Kemâlüddîn Abdürrezzâk Kâşânî ve Tefsiri Te'vîlâtü'l-Kur'ân'ın Tefsir Metodolojisi Açısından Tahlil ve Tanıtımı, (Basılmamış Yüksek Lisans Tezi, Erciyes Ü. Sos. Bil. Ens.Kayseri, 2009).

» Kehhâle, Ömer Rıza, Mu'cemu'I-Müellifîn Terâcim-i Musannifi'l-Kütübi'l-Arabiyye, Beyrut, 1993, (I-IV).

» Komisyon, Türkçe Sözlük, TDK. Basım Evi, Ankara, 1988, (I-II).

" Konevî, Sadreddin, Vahdet-i Vücûd ve Esasları, çev. Ekrem Demirli, İz Yayıncılık, İstanbul, 2012. 
Kurtuluş, Rıza, “Kâşân”,DiA, Ankara, 2002, XXV/3-4.

") Lory,Pierre, Kâşânî'ye Göre Kur'an'ın Tasavvufî Tefsiri, çev. Sadık Kılıç, İnsan Yay. İstanbul, 2001.

" Macdonald, D.B.,"Abdürrezzâk Kâşânî", M.E.B.i.A., İstanbul, 1960, I/106.

» Mollaibrahimoğlu, Süleyman, Süleymaniye Kütüphanesinde Bulunan Yazma Tefsirler (Metod ve Kaynakları), İstanbul, 2002.

» Nurullah Şüsteri, Mecâlisü'l-Mü'minîn, Tahran, 1365, (I-IV).

» Nuveyhid, Adil, Mu 'cemu'l-Müfessirîn min Sadri'l-Islâm Hatta'l- 'Aşri'l-Hâdır, Beyrut, 1983.

» Öztürk, Mustafa, Kur'an ve Aşırı Yorum, Ankara Okulu Yay.3. Baskı, Ankara, 2014.

Reşid Rıza, Tefsîr-u Kur'âni'l-Hakîm, Dâru'I-Menâr, Kahire, 1947, (I-XII).

" Sem 'ânî, Ebû Saîd Abdilkerîm b. Muhammed b. Mansûr et-Temîmî, el-Ensâb, tahk., Abdullah Ömer Bârûnî, Beyrut, 1988, (I-V).

» Serkis, Yusuf Illyân, Mu 'cemu'l-Matbûa 'ti'al-Arabiyye ve'l-Muarrabe, Kahire, ts.

» Şerbetçi, Azmi, “Kutbüddîn-i Şîrâzî”, DiA, Ankara, 2002,XXVI/487-488.

" Şirinov, Agil, “Tûsî, Nasîruddîn”,DiA, Ankara, 2012, XXXXI/437-441.

Togan, Zeki Velidi, Umûmî Türk Tarihine Giriş, İstanbul, 1981.

»Udnerevî, Ahmed b. Muhammed, Tabakâtu'l-Müfessirîn, tahk. Süleyman b. Salih el-Hızzî, Medînetü'l-Münevvere, 1997.

» Uludağ, Süleyman, "Kâşânî Abdürrezâk",DiA, Ankara, 2002, XXV/5-6.

» Ünver, Mustafa, Hurufilik ve Kuran, Nesimî Örneği, Fecr Yay. 1. Baskı, Ankara, 2003.

"Yuvalı, Abdülkadir, "Ebû Saîd Bahâdır Hân", DiA, İstanbul, 1994, X/218-219.

" _. "IIhanlılar",DiA, İstanbul, 1994, XXII/105- 107.

" Zehebî, Muhammed Hüseyn et-Tefsîr ve'l-Müfessirûn, Mektebetü Vehbe, Kahire, ts. (I-III).

" Zirikli, Hayrettin, el-A'lâm Kâmûs-u Terâcim li Eşher'ir-Ricâl ve'n-Nisâ mine'l-Arabi ve'lMüsta'ribîn, Beyrut, 1997, (I-VIII). 